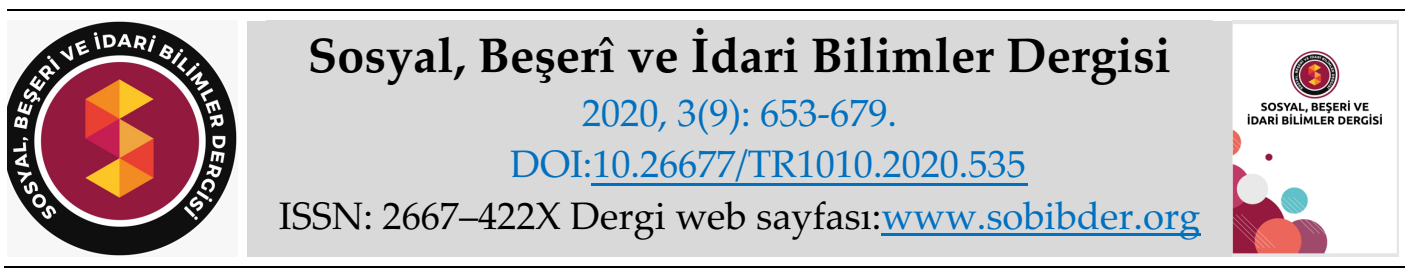

ARAȘTIRMA MAKALESI

\title{
Sembolik Tüketimin Satın Alma Niyetine Etkisinde Ünlü Hayranlığının Rolü: Ön Ergen Tüketicilere Yönelik Bir Araştırma
}

Arş. Gör. Dr. Hale ÇOLAKOĞLU, Çanakkale Onsekiz Mart Üniversitesi, Biga İ.İ.B.F., Çanakkale, e-posta: halecelikkan@comu.edu.tr

ORCID: https://orcid.org/0000-0003-3435-4475

Dr. Öğr. Üyesi Nilay KÖLEOĞLU, Çanakkale Onsekiz Mart Üniversitesi, Biga İ.İ.B.F., Çanakkale, e-posta: nkoleoglu@yahoo.com

ORCID: https://orcid.org/0000-0002-6153-719X

Öz

Hızla değişen dünyada tüketiciler artık ürünlerin yalnız fonksiyonel özellikleri ile değil, sembolik özellikleri ile de ilgilenmektedir. Bu durum ürünlerin taşıdığı sembolik anlamların öneminin giderek artmasına neden olmaktadır. Tüketimin geldiği bu noktada diğer bir önemli konu da pazarlamacıların önemli bir pazar olarak gördükleri, genç ve çocuklardan oluşan daha küçük yaştaki tüketicileri odağına almaya başlamasıdır. Bugünün çocuk geleceğin yetişkin tüketicileri olarak bu kitlenin satın alma niyeti ve bu niyeti etkileyen faktörler araştırılması gereken konular arasındayken literatürde konuyla ilgili büyük boşluk gözlemlenmektedir. Çalışmanın amacı sembolik tüketimin ön ergen olarak ifade edilen 10-14 yaş grubu tüketicilerin satın alma niyetine etkisini belirlemek ve bu etkide ünlü hayranlığının aracı rolü olup olmadığını ortaya koymaktır. Araştırma kapsamında Çanakkale'de yaşayan 10-14 yaş grubu çocuklardan elde edilen veriler analiz edilerek model test edilmiştir. Analizler sonucunda, sembolik tüketim ile satın alma niyeti arasında anlamlı ve pozitif ilişki olduğu tespit edilmiştir. Ayrıca sembolik tüketimin satın alma niyetine etkisinde ünlü hayranlığının aracılık rolünün bulunduğu tespit edilmiştir.

* Bu çalışma Dr. Öğr. Üyesi Nilay KÖLEOĞLU danışmanlığında Öğrenci Hale ÇOLAKOĞLU tarafından hazırlanan ve 10.01.2020 tarihinde savunulan “Sembolik Tüketimin Ön Ergen (Tween) Tüketicilerin Satın Alma Niyeti Üzerine Etkisi: Sosyal Ajanların Aracılık Rolü" başlıklı doktora tezinden yararlanılarak hazırlanmıştır.

Anahtar Kelimeler: Sembolik Tüketim, Satın Alma Niyeti, Ünlü Hayranlığı.

Makale Gönderme Tarihi: 15.06.2020

Makale Kabul Tarihi: 02.09.2020

\section{Önerilen Atıf:}

Çolakoğlu, H. ve Köleoğlu, N. (2020). Sembolik Tüketimin Satın Alma Niyetine Etkisinde Ünlü Hayranlığının Rolü: Ön Ergen Tüketicilere Yönelik Bir Araştırma, Sosyal, Beşeri ve İdari Bilimler Dergisi, 3(9): 653-679.

(C) 2020 Sosyal, Beşerî ve İdari Bilimler Dergisi. 


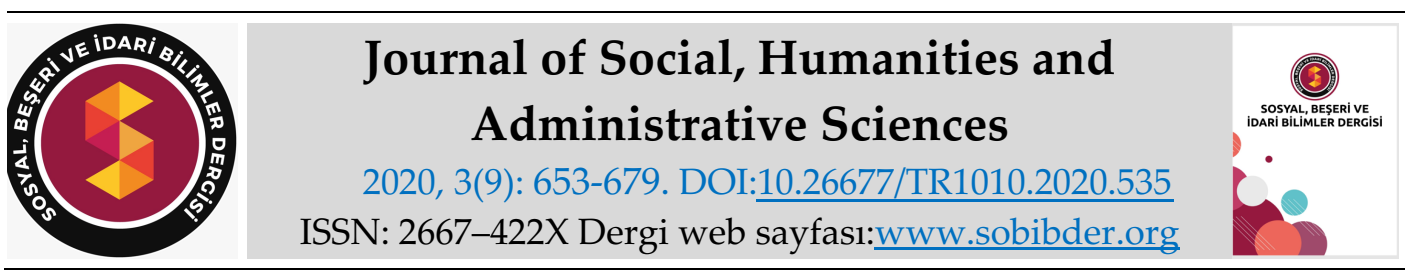

RESEARCH PAPER

\title{
The Role of Celebrity Adoration in The Effect of Symbolic Consumption to Purchase Intention: A Research on Tween Consumers
}

Dr. Hale ÇOLAKOĞLU, Çanakkale Onsekiz Mart University, Biga Faculty of Economics and Administrative Sciences, Çanakkale, e-mail: halecelikkan@comu.edu.tr

ORCID: https://orcid.org/0000-0003-3435-4475

Assistant Prof. Dr. Nilay KÖLEOĞLU, Çanakkale Onsekiz Mart University, Biga Faculty of Economics and Administrative Sciences, Çanakkale, e-mail: nkoleoglu@yahoo.com

ORCID: https://orcid.org/0000-0002-6153-719X

\begin{abstract}
In a rapidly changing world, consumers are now concerned not only with the functional features of the products, but also with their symbolic features. This situation causes the importance of symbolic meanings of products to increase gradually. Another important issue at this point of consumption is that marketers begin to focus on younger consumers, young and children, that they see as an important market. As the adult consumers of today's children and the future, the audience's intention to purchase and the factors affecting this intention are among the topics that should be investigated, while a large gap is observed in the literature. The purpose of the study is to determine the effect of symbolic consumption and purchase intention of 10-14 age group consumers who are expressed as tweens and to determine whether celebrity adoration influence this effect. Within the scope of the research, the data obtained from 10-14 age group children living in Çanakkale were analyzed and the model was tested. As a result of the analyzes, a significant and positive effect was found between symbolic consumption and purchase intention. It was also found that celebrity adoration mediated the effect of symbolic consumption and purchase intention.
\end{abstract}

Keywords: Symbolic Consumption, Tween Consumer, Purchase Intention, Celebrity Adoration. Received: 15.06 .2020

Accepted: 02.09.2020

\footnotetext{
Suggested Citation:

Çolakoğlu, H. and Köleoğlu, N. (2020). The Role of Celebrity Adoration in The Effect of Symbolic Consumption and Purchase Intention: A Research on Tween Consumers, Journal of Social, Humanities and Administrative Sciences, 3(9): 653-679.

(c) 2020 Sosyal, Beşerî ve İdari Bilimler Dergisi.
} 


\section{Gíriş}

Tüketim eyleminin, insanoğlunun dünyaya ilk gelişiyle başladığını söylemek mümkündür. Pek çok eylem ve kavramda olduğu gibi tüketim eyleminde de zaman içinde değişiklikler yaşanmıştır. Dolayısıyla tüketim eyleminin her yeni neslin kendine ait teknolojik, ekonomik, sosyal, kültürel farklı dinamiklerden etkilendiği, böylelikle zaman içinde değiştiği açıktır. Son yıllarda teknoloji ve internette yaşanan gelişmelerin insana dair hemen her şeyi akıl almaz bir hızla değiştirmesinden tüketim eylemi de nasibini almış gözükmektedir. Farklı nesillerin tüketim eyleminde yaşanan değişikliklerin ötesinde, tüketim kararlarında her geçen gün daha fazla rol oynamaya başlayan çocukların tüketim eylemleri, bu anlamda büyük önem taşımaktadır.

Günümüz çocuklarının bilgi düzeyleri geçmişe kıyasla oldukça fazladır ve çocukların bilgiye ulaşabilmeleri daha kolaydır. Bu da çocukların hem ailelerinin hem de bireysel satın alma kararlarında daha etkin olması sonucunu doğurmuştur. Bu gelişmeler ışığında işletmelerin söz konusu değişime uyum sağlaması ve yeni duruma uygun pazarlama stratejileri geliştirmesi gerekliliği kaçınılmaz olmuştur. 2020 yılı TUİK verilerine göre Türkiye'deki toplam nüfusun $\% 28$ 'ini 0-17 yaş grubu çocuklar oluşturmaktadır. Bu çocukların da \%27'si yani toplam nüfusun $\% 7^{\prime}$ si 10-14 yaş grubunu ifade eden bugünün çocuk, geleceğin yetişkin tüketicileri olarak karşımıza çıkmaktadır.

Öte yandan hızlı değişimlerin yaşandığı günümüzde her alanda olduğu gibi, tüketim ve alışveriş gibi alanlarda da semboller önem kazanmaya başlamıştır. Eğer bir ürün toplumsal tanınmayı ifade edebilecek düzeyde sembolik bir anlam ifade ediyor ve bu anlam ürünle ilişkilendiriliyorsa bu ürün toplumun farklı bölümlerini anlamlandırma ve bu bölümlerle ilişkilendirilmede kullanılabilir (Grubb ve Grathwohl, 1967: 24). Bu nedenle tüketiciler ürünleri / markaları satın alınırken, ekonomik veya işlevsel faydasından çok taşıdığı anlamları dikkate almaktadır (Torlak vd., 2006: 143).

Bu bilgiler ışığında, ön ergen tüketicilerin satın alma niyetinin ile sembolik tüketime etkisine ve bu etkide ünlü hayranlığının aracılık rolünü incelemeye yönelik bu çalışma kavramsal çerçeve ve alan araştırması olmak üzere iki kısımdan oluşmaktadır. Kavramsal çerçeve kısmında, sembolik tüketim, ön ergen tüketici, satın alma niyeti, ünlü hayranlığı ve söz konusu kavramlar arasındaki ilişki mevcut alan yazın çerçevesinde irdelenmektedir.

Alan araştırması kısmında ise, sembolik tüketim, ön ergen tüketici, ünlü hayranlığı ve satın alma niyetine ilişkin mevcut alan yazın dikkate alınarak hazırlanmış anket formunun veri toplama aracı olarak kullanıldığı bir alan araştırması oluşturmaktadır. Alan araştırması için Çanakkale ili tercih edilmiştir. Araştırmada 10-14 yaş tüketici pazarı hakkında bilgi toplamak ve bu tüketicilere hitap eden firmalara bu tüketicilerin profili hakkında bilgi sağlamak amaçlanmıştır.

Yapılan alan araştırması ile 10-14 yaş tüketicilerin satın alma niyetinin sembolik tüketime etkisi ve bu etkide ünlü hayranlığının aracılık rolü ortaya konulmaktadır. Böylece ön ergen tüketicilerin satın alma niyeti ile ürünün sembolik özelliklerinin etkileşiminin belirlenmesi ve bireyin sosyalleşmesinde etkili olan ünlü hayranlığının bu etkileşimdeki rolünün ortaya çıkarılması hedeflenmiştir.

\section{KAVRAMSAL ÇERÇEVE}

\section{Sembolik Tüketim}

Sembol, bir varlığı ifade etmek için kullanılan bir başka varlıktır. Ürünlerin sembolik anlam taşıması için nasıl bir ihtiyacı karşıladığının bir önemi yoktur. Sembolik anlamlar kimi ürün veya 
nesneler için zenginlik göstergesi anlamı taşırken, kimi ürün ve nesneler için ise farklı gizli anlamlar taşıyor olabilir. Bu nedenle bir ürün veya nesneye yüklenen anlam tüketicinin o ürün veya nesneyi benimsemesi açısından önemli rol oynamaktadır (Torlak vd., 2006: 117).

Odabaşı (2006)' ye göre semboller, "nesne ya da fikir gibi başka bir şeyin yerine geçen işaretler" olarak açıklanmaktadır. Diğer bir deyişle, semboller herhangi bir şeyi veya bir ilişkiyi temsil eden kapsamlı ve geniş işaretlerdir. İşaretleri ise iletişimde kullanılan sözcük, jest, resim ve logolar şeklinde tanımlamak mümkündür. Başka bir ifadeyle işaretler herhangi bir şeyi betimlemeye yarayan belirti ve göstergelerdir (Odabaş1, 2006: 84). Zaltman (2003)'a göre semboller, tüketicilerin dış dünyalarına köklenmiş olup, bu dış dünyadaki tecrübelerine göre anlam kazanmaktadır ve bunun yanı sıra gizli ve özel anlamları aktarmaktadır (Quliyev, 2012: 46).

Sembolik tüketim ise, ürün veya markaların üstlendikleri sembolik değere göre değerlendirilip satın alınması veya tüketilmesidir (Azizağaoğlu, 2010: 33). Yani ürünlerin tüketilmesinin ana nedenini ürünlerin sembolik anlamları oluşturmaktadır. İnsanlar tükettikleri ürünlerle kendi çevreleriyle iletişim kurmaktadır. Tüketilen bu ürün ve hizmetler aracilığıyla tüketiciler kendi sosyal sınıfları ve statüleri ile ilgili bilgi aktarmaktadır (Azizağaoğlu, 2010: 41). Ürünün yalnızca ne yapabileceği yanında ne anlama geldiğini de dikkate alan tüketiciler, sembolik tüketimi tüketim kültürünün ana unsurlarından biri haline getirmektedir.

Haire (1950), bir ürünün fonksiyonel faydasının yanı sıra sembolik cazibesi için de satın alınabileceğini ifade etmiştir. Levy (1959:119) yayınladığı çalışmasında yöneticilerin sattıkları ürünlerin fonksiyonel ihtiyaçları karşılamasına ek olarak sembolleri de sattı̆̆ının farkında olması gerektiğini vurgulamıştır (Ünal, 2014: 48).

Sutherland ve Sylvester (2003: 112) sembollerin ürün farklılığ1 yaratma noktasındaki etkisini şu şekilde ifade etmektedir: "Aynı ürün kategorisindeki markalar arasında bulunan farklılıklar çok ufak olabilir, fakat dikkatin odak noktası markanın bu sembolik taraflarına yöneltilince, bu küçük farklılıklar dengeyi bozabilir." Bu bakımdan sembollerin markanın temel değerini yansıtmakla birlikte herkesin anında tanıyabileceği kadar ayırt edici olması gerekmektedir (Lindstrom, 2006: 207).

Pazarlamacılar markalarının ardında gizlenen anlamları göstermek amacıyla semboller yaratırlar. Tüketiciler yaratılan bu sembollerle ilişkiler kurar ve uydurulmuş hayal ürünü karakterler bile tüketicilere gerçek gibi gelir (Solomon, 2003: 47). Featherstone (2005: 186); "reklam, medya ve malların teşhirine yönelik teknikler yoluyla tüketim kültürü, malların orijinal kullanım amacını ya da anlamını istikrarsızlaştırarak bunlara, bütün bir duygular ve arzular silsilesine davetiye çıkartabilen yeni imgeler ve göstergeler iliştirir" sözleriyle konuya açıklık getirmektedir.

\section{Önergen Kavramı ve Önergen Tüketici}

Ergenlik, biyolojik değişikliklerin yanında psikolojik, fiziksel, sosyal ve bilişsel olarak da değişimlerin yaşandığı, cinsiyet özelliklerinin kazanıldığı, bunlara ek olarak siyasi, ekonomik, duyuşsal, sosyal, kültürel ve yasal konularda da değişikliklerin yaşandığı, bireyin sorumluluğunun artış gösterdiği bir geçiş evresi olarak tanımlanmaktadır (Senemoğlu, 2010: 5657). Koç (2004: 233)'a göre ergenlik, çocukluk döneminin sona ermesi ile başlayan ve fiziksel erişkinliğe ulaşıncaya kadar süren gelişim dönemini ifade etmektedir. Kızlarda adet görme erkeklerde ise kılların çıkması ve sesin kalınlaşması bu dönemin fizyolojik ilk belirtileri arasında yer almaktadır. 
Ergenliğin başlangıcı ve ne kadar süreceği tam olarak kestirilemediği gibi, sürecinin de ne şekilde başlayıp biteceği, nasıl devam edeceği ile ilgili de kesin bir şey söylemek mümkün değildir. Bu dönem her birey için farklı değişiklikler ve belirsizlikler içerir. Ergenlik dönemi yaklaşık olarak 10-12 yaşlarında başlar. Ön ergenlik dönemi, 10-12 yaşları ile 14 yaş arasında yaşanan hızlı değişmeleri içeren ve erinlik olarak isimlendirilen dönemdir. Orta ergenlik dönemi, 15-17 yaş arası değişimlerin neredeyse tamamlandığı dönemi ifade etmektedir. Son ergenlik dönemi ise, 18 ile 21 yaş arası bireyin bir yetişkin görüntüsüne ulaşmaya başladığı ve yetişkin rollerini üstlendiği dönemdir (Dinç, 2010: 26).

Ön ergenlik dönemi dış görünüşün önem kazandığı bir dönemdir. Bireyin görünüşüne verdiği önem benliğinin oluşmasına katkı sağlar. Bu dönemde birey benliğini tanıma arayışı ile dini konulara, kahramanlara, çeşitli ideoloji ve öğretilere ilgi duyabilir. Kendi içinde yaşadığı kararsızlık bu dönemdeki bireyleri bir araya getirerek dayanışma grupları oluşturmalarına sebep olur. Ön ergen için bu dönem çocukluk döneminde öğrendiği kurallar ile oluşturması beklenen değerler arasında kaldığı, kendini eleştirdiği ve akranları ile rekabet içinde olduğu bir dönemi ifade etmektedir (Güler, 2013: 43).

Günümüzde ön ergenler bugünün tüketicisi olarak geleceğin potansiyel müşterisi konumundadır. Markaların ön ergen pazarı için geliştirdikleri pazarlama stratejilerinin amacı, onları tüketime yönlendirmek ve gelecekte markanın sadık müşterisi haline getirmektedir. $\mathrm{Bu}$ pazar, eğlence, gıda, giyim gibi pek çok sektörde yerini almış durumdadır. Uluslararası bir fastfood zinciri olan lokantadan çocuklara verilen hediyeyi almak için ailesini ikna eden çocuk satın alma sürecinin aktif üyesi olmaktadır. Hayranı olduğu bir kahramanın resminin bulunduğu giysiyi satın alma konusunda ailesini ikna eden çocuk tüketici, bu şekilde ailesinin satın alma davranışını yönlendirerek tüketimdeki yerini göstermektedir (Aydemir, 2005: 84; Kadıŏlu, 2016: $31)$.

Türkiye'de 2020 yılı Nisan ayı verileri göre 22 milyon 786 bin 798 çocuk bulunmaktadır. Yaş grubuna göre incelendiğinde, geçtiğimiz yıl çocuk nüfusun yüzde 27,9'unu 0-4 yaş grubu, yüzde $27,7^{\prime}$ sini 5-9 yaş grubu, yüzde 26,9'unu 10-14 yaş grubu ve yüzde 17,4'ünü ise 15-17 yaş grubu çocuklar oluşturmuştur (TUİK, 2020). Bu verilere göre Türkiye'de de çocuk nüfusunun toplam nüfus içinde ciddi oranda bir payının ciddi bir oranda olduğu görülmekte, Türkiye çocuk pazarı da firmalar ve özellikle pazarlamacılar için önemli bir kazanç sağlama alanı olarak ele alınmaktadır.

Nüfus içerisindeki paylarının yanı sıra, kendi satın alma kararları ile aile satın alma kararlarına yaptıkları etki, yetişkin oldukları dönemde davranış modellerinin yetişkin dönemdeki tüketici davranışı modelini etkiyecek olması sebebiyle çocuk ve ergen dönemi bireyleri günümüz firmaları için özel bir tüketici grubu haline gelmiştir (Loudon ve Della Bitta, 1988; aktaran Şener ve Babaoğul, 2007: 128)

\section{Tüketici Sosyalleşmesi ve Sosyalleşme Aracı Olarak Ünlü Hayranlığı}

Sosyalleşme, toplum ve bireyin karşılıklı olarak birbirini etkilediği bir değişim sürecidir (Erzen ve Yalın, 2012: 51). Bu süreç, erken çocukluk döneminde belirgin hale gelmekle beraber annebaba-çocuk, çocuk-kardeş, çocuk-akran, çocuk-yakın çevre arası etkileşimi kapsayarak ergenlik döneminde de önemini korumaktadır. Bu öğrenme süreci, bireyin belirli bir grubun aktif bir üyesi ve o grubun diğer üyeleri ile değer, inanç ve davranışlarını paylaşmasıyla hayatı boyunca devam etmektedir (Gander ve Gardiner, 2010: 297).

Tüketici sosyalleşmesi kavramı ise kişinin bir tüketici olduğunun kabul edilmesi için ihtiyaç duyulan bilgi, beceri, tutum ve davranışları kazanım süreci olarak tanımlanmaktadır. Başka bir 
deyişle tüketici sosyalleşmesi kişinin tüketici kimliği edinmesi sürecini ifade etmektedir (Gültekin ve Erol, 2014: 117).

Başka bir tanımda tüketici sosyalleşmesi genç bir bireyin tüketici olarak sahip olduğu bilgi, yetenek ve tutumların ortaya çıartma süreci olarak açılanmıştır. Bu nedenle tüketici sosyalleşmesinin bireyin nasıl bir tüketici olduğuna odaklandığını söylemek mümkündür (Dal ve Dal, 2015: 374).

Sosyalleşmenin hayat boyu, tüketici sosyalleşmesinin ise yoğun olarak çocukluk ve gençlik dönemlerinde yaşandığı düşünüldüğünde, Türk toplum yapısındaki gibi genç nüfusun toplam nüfustaki oranının yüksek olduğu toplumlarda çocukların da tüketici olarak ortaya çıkmasının önemi de artmaktadır. Çünkü çocukluk döneminde kazanılan tecrübeler sonraki dönemde tüketim anlayışının şekillenmesinde önemli bir role sahip olacaktır (Ward, 1974'den aktaran; Madran ve Bozyiğit, 2013: 721).

Çocukların tüketici olarak sosyalleşmesi yetişkin tüketiciler olma yolunda geçirdikleri aşamalardan oluşan bir süreçtir. Bu aşamaları belirleyen birçok unsur vardır. Bunlar tüketimle ilgili olayları anlayabilme, bilginin elde edilme şekli, karar verme becerileri, ikna etme becerileri, ürünü değerlendirme ve sahip olunan tutumlar, görev ve sorumluluklar gibi unsurlardır (Yücel, 2003: 25).

Birey zaman zaman başkasının bilgi ve deneyimlerinden faydalanarak, onları taklit ederek öğrenme süreci geçirebilir. Konuşma, yeme alışkanlıkları, moda tercihleri gibi pek çok konuda örnek alınan bireyler ve geliştirilen davranış biçimleri olabilir. Bu şekilde gerçekleştirilen öğrenmeye modelleme yolu ile öğrenme adı verilmektedir (Çelik, 2003: 46). Bu öğrenme şekli genellikle aile, akran veya ünlü kişilerin rol model olarak görülmesi ve bireyin davranışlarını etkilemesi yoluyla tüketici sosyalleşmesi sürecine yansımaktadır.

Aile ve akranların yanı sıra ünlü kişiler de bireyin tüketici olarak sosyalleşmesinde etkili bir sosyalleşme ajanı olarak karşımıza çıkmaktadır. Ünlü ve tanınmış kişiler tüketici satın alma davranışlarında olumlu etki yaratan önemli bir referans grubunu oluşturmaktadırlar. Bu grubu oluşturan ünlüler başarılı iş insanları, dizi ve sinema oyuncuları, mankenler, sporcular, müzisyenler, gazeteciler gibi farklı branşlarda kendini gösteren kişilerdir (Albar ve Öksüz, 2013: 421).

Ünlü kişilerin tüketicilerin sembolik olarak gerçekleştirdikleri tüketim davranışlarında etkili olduğunu söylemek mümkündür. Tüketicinin sevdiği ve güvendiği bir kişi tarafından tanıtılan veya tavsiye edilen bir ürün tüketicinin fiziksel olarak ihtiyaç duymasa dahi satın alma eğilimi göstermesine neden olmaktadır. Bu sayede markalar reklam yüzü olarak seçtikleri ünlü kişileri kullanarak ürün veya marka ile tüketici arasında uzun ömürlü bir bağ kurmaktadırlar (Dwivedi ve Johnson, 2013: 37).

İnternet ve sosyal medya kullanımındaki artış ile birlikte ünlü kişilerin takip ederek hayatlarının içine kadar girebilen tüketiciler, rol model olarak gördüğü kişilerin davranışlarını taklit ederek onlar gibi olmaya çabalamaktadır. Özellikle çocukluk ve ergenlik döneminde rol model olarak görülen kişilerin karakter oluşumundaki etkisi büyüktür.

Yapılan araştırmalar çocuğun kişilik gelişiminde de rol modelin önemini ortaya koymaktadır. Özellikle çocuğa ebeveyn davranışlarının nedenleri ile birlikte açıklanması taklit yoluyla öğrenmesini kolaylaştırmaktadır. Rol model ile çocuğun bir davranış şekline yönelmesinin sosyal olarak onaylanmış olması önemli bir noktadır (Aydın, 2001: 52).

Rol model olarak görülen veya hayranlı duyulan kişi bireyin kimlik gelişimini de etkilemektedir. Özellikle çocukluk ve ergenlikte müzisyenler, sporcular, oyuncular gibi ünlü 
kişilere beslenen yoğun hayranlık çocuklarda ve gençlerde onları taklit etme, onlar gibi olma ve onların satın aldığı ürünleri satın alma gibi çabalar içerisinde olmalarına neden olmaktadır (Chan ve Zhang, 2007: 142).

Birey çok küçük yaşlardan itibaren birilerinden etkilenmekte ve tüketime yönelik davranışlarında bu kişilere ilişkin gözlemleri etkili olmaktadır. Rol model, çocukların tüketici olarak sosyalleşmesini etkilerken tüketime yönelik kararlarını, tutum ve davranışlarını, markalara ilişkin algılarını da şekillendirmektedir (Martin ve Bush, 2000: 441-443).

\section{Satın Alma Niyeti}

Niyet, Türk Dil Kurumu'nun Bilim ve Sanat Terimleri Sözlüğündeki anlamı ile "Bir şeyi yapmayı önceden isteyip düşünme, maksat" şeklinde tanımlanmaktadır (TDK, 2019). Niyet kavramı Tek (1999:215) tarafından "Bir şeyi yapmayı önceden isteyerek tasarlama anlamına gelmekte olup herhangi bir davranışı gerçekleştirmeye yönelik fiili iradenin önemli bir göstergesi" olarak ifade edilmiştir.

Pazarlama açısından niyet kavramını, satın alma seçeneklerini değerlendirme ve satın almanın gerçekleşmesi aşamaları arasında gerçekleştiği şeklinde yorumlamak mümkündür. Buradan hareketle satın alma niyeti, müşterinin bir ürün veya hizmeti satın alması yönündeki algısının kanaat seviyesidir (Bergeron, 2004: 117). Başka bir söylemle satın alma niyeti, bireyin bir ürün veya hizmeti satın alma eğilimi şeklinde ifade edilebilir (Tek, 1999:215).

Ajzen'e (2005:100-101, 115) göre satın alma niyeti gerçek davranışla ilişkilidir. Niyetler, çeşitli davranış eğilimlerini doğru bir şekilde tahmin edebilir. Niyet ve davranış arasındaki ilişkide çoğu zaman düşük korelasyonlar gözlemlense bile bu ilişki genel itibari ile önem arz etmektedir. (Çetinkaya, 2019:74).

Dodds vd. (1991), satın alma niyetini, müşterinin belirli bir ürün veya hizmeti satın alma olasılığ olarak tanımlamış (Lien vd., 2015:212) ve satın alma niyetinin tüketicinin herhangi bir satın alma kararı almadan önce yaşadığı duygu, düşünce ve deneyimler ile dış etkenlerden oluştuğunu ifade etmiştir (Yeh, 2015: 36). Schifman ve Kanuk (2007)'a göre satın alma niyeti tüketici davranışını tahmin edilmesini için önemli bir göstergedir. Olumlu bir satın alma niyeti, tüketiciyi satın almayı gerçekleştirmeye yönelten en önemli itici güç olarak karşımıza çıkmaktadır (Wu vd., 2011: 32).

Tüketici satın alma niyetinin temelinde ürün veya hizmet seçimi, marka tercihi, zaman ve miktar gibi bilgiler yer almaktadır. Satın alma niyetinin biliniyor olması, tüketicinin satın alacağı ürün veya hizmeti ve satın alma davranışı ihtimalini önceden anlayabilmenin bir yolu olarak ortaya çıkmaktadır. Bu nedenle firmalar tüketici niyetinin ölçülmesine yönelik araştırmalar yaparak bu bilgileri elde etmeye çalışmaktadır. Mevcut müşteriler ve potansiyel müşteriler açısından değerlendirildiğinde mevcut müşteriyi elde tutma maliyetinin yeni müşteri elde etme maliyetinden düşük olduğu bilgisi doğrultusunda firmalar ve pazarlamacılar açısından satın alma niyetinin önemi daha da artmaktadır (Kozak ve Doğan, 2014: 65).

\section{YÖNTEM}

\section{Araştırmanın Modeli ve Hipotezleri}

Bireyin sosyalleşme çabası elbette ki kendine yakın bulduğu, rol model olarak gördüğü unsurların olduğu bir gruba dahil olmak içindir. Medyanın etkisi ile çocuklar ve gençler çeşitli kişilere özenmekte ve onları rol model olarak görmektedir. İnternetin ve sosyal medya 
kullanımının yaygınlaşması ile birlikte birey ekranda görüp hayranı olduğu kişiyi takip ederek onunla iletişim kurabilmekte, rol model aldığı kişi ile sanal ortamlarda bir araya gelmektedir. Televizyon ve internet ortamlarında sunulan özendirici yaşamlar ve karakterler çocukların ve gençlerin hayranı olduğu ünlü ile bağ kurma isteğini daha da arttırmaktadır. Hayranı olduğu ünlü ile arasında bir bağ kurmaya çalışan birey tüketimini de ona göre şekillendirmekte, özellikle onların kullandığı veya önerdiği, üzerinde onları resimlerinin veya onları çağrıştıracak sembollerin olduğu ürünleri tercih etme yoluna gitmektedir. Bu yolla birey, hayranı olduğu ünlünün bulunduğu topluluğa dahil olmuş hissederek bunun hazzını yaşmaktadır (Kadıŏlu, 2013: 107).

Çocukların tüketici olarak sosyalleşmesinde de ünlü hayranlığı etkisi bu şekildedir. Temelde ünlü hayranlı̆̆ı akran baskısından kaynaklanan, sevdikleri spor, müzik ve/veya eğlence yıldızının adını taşıyan en iyi bilinen markalara yönelmektir (Dotson ve Hyatt, 2005; Fan ve Li, 2009: 7). Çocuklar ve ergenler genellikle hayranı oldukları sporcu veya şarkıcıya büyük saygı duyarlar. Ünlü hayranlığı yaygın olduğu için bu durum bir pazarlama stratejisi olarak kullanılır ve bu şekilde hayranlar markanın ürünlerini satın almaya ikna edilir (Chiou vd., 2005: 318). Keşfetme dürtüsü ile hareket eden çocuklar üzerinde medyanın, özellikle de televizyonun etkisi yadsınamaz düzeydedir. Çocukların alacakları kararlarda etkili bir araç olan televizyon ve özellikle reklamlar içerdikleri kurgusal, renkli, müzikli öğeler ile çocukları etkisi altına almaktadır (Engin, 2013: 223).

Araştırmanın modeli, gerçekleştirilen literatür taraması sonrasında çalışmalarda kullanılan değişkenler temel alınarak oluşturulmuştur. Şekil 1'de araştırmanın modelinin temel değişkenleri verilmiştir. Modele göre sembolik tüketimin satın alma niyeti üzerine etkisi araştırılmaktadır. Öte yandan sembolik tüketimin ünlü hayranlığı üzerine etkisi ile ünlü hayranlığının satın alma niyeti üzerine etkisi araştırılan diğer bir konudur.

$\mathrm{Bu}$ amaçlar doğrultusunda araştırmanın hipotezleri aşağıdaki gibidir:

$\mathrm{H}_{1}$ : Sembolik tüketimin satın alma niyeti üzerinde anlamlı ve pozitif etkisi vardır.

$\mathrm{H}_{2}$ : Sembolik tüketimin satın alma niyeti üzerine etkisinde ünlü hayranlığının aracılık rolü vardır.

$\mathrm{H}_{2 a}$ : Sembolik tüketimin ünlü hayranlığı üzerinde anlamlı ve pozitif etkisi vardır.

$\mathrm{H}_{2 b}$ : Ünlü hayranlığının satın alma niyeti üzerinde anlamlı ve pozitif etkisi vardır.

Bu hipotezler doğrultusunda çalışmanın modeli aşağıdaki gibidir:

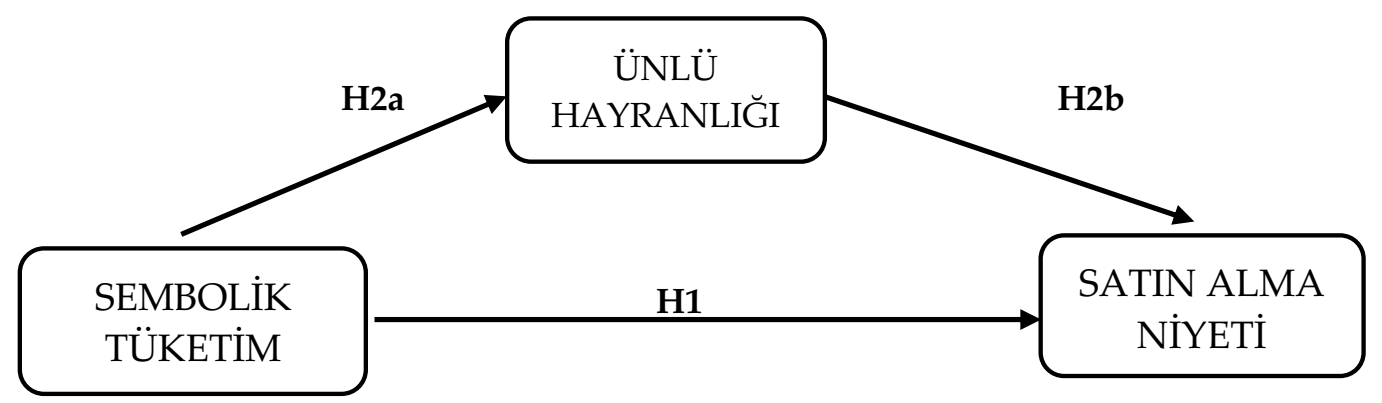

Şekil 1. Araştırma Modeli

\section{Araştırmanın Örneklemi ve Veri Toplama}

Araştırmanın örneklem seçimi için araştırmada kullanılması planlanan değişkenlere yönelik literatür taraması sonucunda ulaşılan çalışmalar göz önünde bulundurularak, seçilen değişkenler 
için araştırmanın evrenini Çanakkale ilinde yaşayan 10-14 yaş grubu ön ergen tüketiciler oluşturmaktadır. Araştırmanın örneklemi ise Çanakkale ili merkez ilçesinde yaşayan 10-14 yaş grubu ön ergen tüketiciler olarak kabul edilmiştir. Çanakkale İl Müdürlüğü verilerine göre Çanakkale ilinde eğitim öğretimine devam eden 10-14 yaş grubu ön ergen sayısı yaklaşık olarak 12700 olarak hesaplanmıştır (https://www.meb.gov.tr).

Örneklem büyüklüğünün belirlenmesi birçok açıdan araştırmacı için büyük önem taşımaktadır. Araştırmacı örneklem hacmini istatistiksel yöntemlerle hesaplayabileceği gibi, zaman, bütçe, evrenin homojenliği vb. etkenler doğrultusunda yargısal bir sonuca varabilir (Gegez, 2007: 258). Bu araştırmanın örneklem büyüklüğünün belirlenmesinde Saunders ve arkadaşları tarafından oluşturulan '\%95 Güven Düzeyinde Farklı Anakütle Büyüklükleri İçin Örnek Hacimleri' tablosundan yararlanılmıştır (Saunders vd., 2009: 219). Tabloya göre ana kütlesi 10000 olan bir araştırmanın \%95 güven düzeyinde uygun örneklem miktarı 370'tir. Bu doğrultuda araştırmanın örneklem büyüklügü 470 olarak hesaplanmıştır.

Çalışmada araştırma verilerinin toplanmasında Milli Eğitim Müdürlügü̈'nden alınan izin ile tesadüfî örnekleme yöntemlerinden kümelere göre örnekleme yöntemi kullanılmıştır. Kümelere göre örneklemede araştırmacının elinde seçim yapmak için kullandığı liste toplam bireyler değil, toplam kümeler listesidir. Araştırmacı elindeki kümelerden birini veya birkaçını tesadüfen seçer (Gegez, 2007: 245).

Çalışma kapsamında veriler mevcut literatürden yararlanılarak geliştirilen anket formu aracılığ 1 ile toplanmıştır. Veri toplama aracı olarak anket formunun tercih edilmesinin birçok nedeni bulunmaktadır. Bunların başlıcaları; araştırmacının amacını sorulara dönüştürerek cevaplayıcıya sunması, soruları standartlaştırarak bütün cevaplayıcılara aynı tür soruların yöneltilmesini sağlaması, veri analizini kolaylaştırması ve hızlandırması, pazarlama alanındaki varsayımların sayısal temel oturtulmasında en güçlü araç olması (Nakip 2006: 120) şeklinde sıralanabilir. Ayrıca, ön ergen tüketici ve tüketici sosyalleşmesi yazınında da anket formu veri toplama yöntemi yaygın şekilde kullanılmıştır.

Geliştirilen anket formu iki grup sorudan oluşmaktadır. Birinci grupta, araştırmaya katılan ön ergenlerin demografik özelliklerine ilişkin dokuz ve hayranı olduğu ünlüye ilişkin üç soru bulunmaktadır. Anket formunda yer alan ikinci grup, sembolik tüketim, ünlü hayranlığı ve satın alma niyetini ölçmeye yönelik yirmi üç sorudan oluşmaktadır. Birinci grup sorular çoktan seçmeli ve açık uçlu sorulardan oluşmaktadır. İkinci grup sorular ise 5'li (1- Kesinlikle Katılmıyorum, 2-Katılmıorum, 3- Fikrim yok, 4- Katılıyorum, 5-Kesinlikle Katılıyorum) şeklinde 5 'li Likert ölçeği ile ölçülmüştür.

Ölçeklerin oluşturulması için geniş bir literatür araştırması yapılmış ve kullanılacak değişkelerle ilgili ölçekler tespit edilmiştir. Anket formunun oluşturulmasında sembolik tüketim için Azizağaoğlu (2010) tarafından kullanılan ölçekte yer alan ifadelerden; ünlü hayranlı̆̆ için Mascarenhas ve Higby (1993) tarafından kullanılan ve Sarıkaya ve Barutçu Türkmen (2014) tarafından Türkçeye çevrilen ifadelerden; satın alma niyeti için Fandos ve Flavian (2006) tarafından kullanılan ölçekte yer alan ifadelerden yararlanılmıştır. Anket formunun oluşturulmasında kullanılan ölçekler Tablo 1'de görülmektedir. Anketteki soru sayısı, anketin tasarımı ve uygulaması yönüyle, anketin genel kabul gören kurallara ve formata uygun olmasına dikkat edilmiştir. Elde edilen verilere paket programlar yardımıyla güvenilirlik analizleri yapılmış ve ön test çalışması sonucunda ankete son şekli verilmiştir.

Veri toplama işlemi için Çanakkale Onsekiz Mart Üniversitesi Sosyal Bilimler Enstitüsü Etik Kurulundan "Etik Kurul Onayı" ve Çanakkale Valiliği İl Milli Eğitim Müdürlügüunden "Makam Onayı" alınmıştır. Veri toplama işlemi 25 Mayıs - 15 Haziran 2018 tarihleri arasında gerçekleştirilmiştir. Anket uygulaması Milli Eğitim Müdürlüğü'nün uygulama prosedürü gereği 
okul idaresine anket formunun teslim edilmesi ve öğretmenler tarafından uygulanması şeklinde gerçekleşmiştir. Çanakkale il merkezinde bulunan 23 devlet, 6 özel okula ulaşılmış, bazı okullar izin alınmış olmasına rağmen gönüllü katılım göstermemiştir. Anket uygulaması sonucunda 677 anket formuna ulaşılmış, yapılan değerlendirmeler sonucunda 647 anketin veri analizinde kullanılabilecek uygunlukta olduğu tespit edilmiştir.

Tablo 1: Anket Formunun Oluşturulmasında Yararlanılan Kaynaklar

\begin{tabular}{|c|c|c|}
\hline Değişken & İfadeler & Yazarlar \\
\hline \multirow{18}{*}{$\begin{array}{l}\text { Sembolik } \\
\text { Tüketim }\end{array}$} & 1. Bu ürünün benim imajıma uygun olduğunu düşünüyorum. & \multirow{18}{*}{ 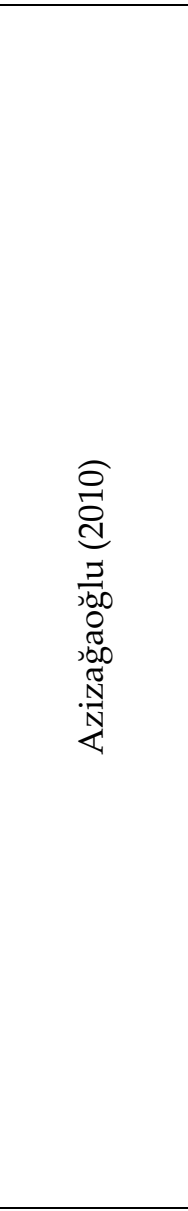 } \\
\hline & 2. Bu ürünün tarzımı yansıttığını düşünüyorum. & \\
\hline & 3. Bu ürün manevi değerlerime uygundur. & \\
\hline & 4. Bu ürünü kullanmak beni olmak istediğim biri gibi gösterir. & \\
\hline & 5. Bu ürün kişiliğime uygundur. & \\
\hline & 6. Ailemdeki diğer kişiler de bu ürünü beğenir. & \\
\hline & 7. Arkadaşlarım da bu ürünü beğenir. & \\
\hline & 8. Bu ürün ünlü kişilerin kullandığı bir üründür. & \\
\hline & $\begin{array}{l}\text { 9. Bu ürünü kullanan diğer kişilerle aramda ortak yönler } \\
\text { olduğunu düşünüyorum. }\end{array}$ & \\
\hline & $\begin{array}{l}\text { 10. Bu ürünü kullanarak toplum içinde kendimi daha rahat ve } \\
\text { güvenli hissediyorum. }\end{array}$ & \\
\hline & 11. Bu ürünü kullanarak modayı takip etmiş olurum. & \\
\hline & $\begin{array}{l}\text { 12. Bu ürün sosyal statüme (toplum içindeki konumuma) } \\
\text { uygundur. }\end{array}$ & \\
\hline & $\begin{array}{l}\text { 13. İnsanlar üzerimde bu ürüne ait isim ya da logoları } \\
\text { gördüklerinde toplumdaki yerim hakkında fikir sahibi olurlar. }\end{array}$ & \\
\hline & $\begin{array}{l}\text { 14. Bu ürünü kullanmak insanların bana güven duymalarına } \\
\text { yardımcı olur. }\end{array}$ & \\
\hline & $\begin{array}{l}\text { 15. Bu ürünü kullanmak toplum içerisinde bana saygınlık } \\
\text { kazandırır. }\end{array}$ & \\
\hline & $\begin{array}{l}\text { 16. Bu ürünü kullanmak benim değerli ve özel biri olarak } \\
\text { görünmeme yardımcı olur. }\end{array}$ & \\
\hline & 17. Bu ürünü kullanmak zengin görünmemi sağlar. & \\
\hline & 18. Bu ürünü kullanarak başarılı biri olduğumu gösterebilirim. & \\
\hline \multirow{5}{*}{$\begin{array}{c}\text { Ünlü } \\
\text { Hayranlığı }\end{array}$} & $\begin{array}{l}\text { 1. Hayranı olduğum kişilerin alışveriş yaptıkları mağazalardan } \\
\text { alışveriş yapmak isterim. }\end{array}$ & \multirow{5}{*}{ 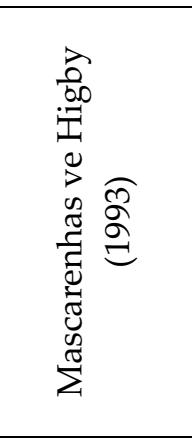 } \\
\hline & $\begin{array}{l}\text { 2. Fiyatları ne kadar yüksek olursa olsun hayranı olduğum } \\
\text { kişilerin kullandığı, tanıttığı ürünleri satın almak isterim. }\end{array}$ & \\
\hline & 3. Moda olan mağazalardan alışveriş yapmak isterim. & \\
\hline & $\begin{array}{l}\text { 4. Sosyal medya ortamında popüler olan ürün ve markaları satın } \\
\text { almayı tercih ederim. }\end{array}$ & \\
\hline & $\begin{array}{l}\text { 5. Alışveriş yaptığım mağaza tercihlerimde hayranı olduğum } \\
\text { ünlülerin etkisi yoktur. (T) }\end{array}$ & \\
\hline \multirow{2}{*}{$\begin{array}{l}\text { Satın Alma } \\
\text { Niyeti }\end{array}$} & $\begin{array}{l}\text { 1. Kullandığım bir ürün tükendiğinde genellikle yine aynı } \\
\text { marka ürünü satın alırım. }\end{array}$ & \multirow{2}{*}{ 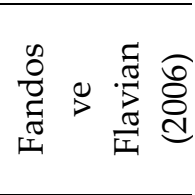 } \\
\hline & $\begin{array}{l}\text { 2. Kullandığım bir ürünü satın aldığım mağazada bulamazsam } \\
\text { aynı marka ürünü bulmak için çaba sarf ederim. }\end{array}$ & \\
\hline
\end{tabular}


Çalışmada ilk temel analizler için SPSS programı, araştırma modelinin ve aracılık etkisinin test edilmesi için ise yapısal eşitlik modellemesi programlarından LISREL yazılım programı kullanılmıştır. Yapısal eşitlik modeli (YEM) ölçülen ve gizil değişkenler arasındaki neden sonuç (nedensel) ilişkilerini test etmede kullanılan istatistiksel bir yaklaşımdır. Psikoloji, pazarlama, eğitim ve sosyolojide kuramsal modellerin işlerliklerinin araştırılmasında kullanılan bir araçtır (Y1lmaz 2004: 77).

\section{BULGULAR}

Çalışmanın bu kısmında, anketi cevaplayanların demografik özelliklerine yönelik sıklık tabloları, hayranı oldukları ünlülere ilişkin tablolar, geçerlilik analizi, güvenilirlik analizi ve çalışma hipotezlerinin test edilmesi için yapılan regresyon analizlerinden oluşmaktadır. Çalışma dahilinde yapılan bu analizler sırasıyla aşağıda açıklanmıştır. Daha sonrasında ise regresyon analizleri doğrultusunda hipotezler ile ilgili elde edilen sonuçlar özetlenmiştir.

\section{Katılımcıların Demografik Özelliklerine İlişkin Bulgular}

Araştırmaya katılan ön ergen tüketicilerin demografik özelliklerine ait sıklık (frekans) ve yüzde dağılımlarını gösteren tablolar aşağıda verilmiştir.

Aşağıdaki tabloda görüldüğü üzere çalışmaya katılanların 353'ü kız, 294'ü oğlandan oluşmaktadır. Bunların toplam içerisindeki yüzdelik dağılımları ise, sırasıyla $\% 54,6$ ve $\% 45,4^{\prime}$ tür. Bu sonuca göre kız ve oğlan katılımcıların sayısının birbirine yakın olduğu görülmektedir.

Tablo 2. Araştırmaya Katılan Ön Ergenlerin Cinsiyet İtibariyle Dağılımları

\begin{tabular}{lcc}
\hline Cinsiyet & S1kl1k & $\mathbf{( \% )}$ \\
\hline Kız & 353 & 54,6 \\
Oğlan & 294 & 45,4 \\
Toplam & $\mathbf{6 4 7}$ & $\mathbf{1 0 0 , 0}$ \\
\hline
\end{tabular}

Araştırmaya katılanların yaş itibariyle dağılımları Tablo 3'de verilmiştir. Tablo 3'de görüldüğü üzere araştırmaya katılanların 276'sı 10, 228'i 11, 47'si 12, 50'si 13 ve 46'sı 14 yaşındadır. Bu dağılımın yüzdelerine bakıldığında katılımcıların yaklaşık \%43'ünün 10, yaklaşık \%35'inin 11 , yaklaşık \% $7^{\prime}$ sinin 12 ve $14, \% 8^{\prime}$ inin ise 13 yaşında olduğu görülmektedir.

Bu sonuçlara göre katılımcıların yaş gruplarına göre eşit dağılmadığı açıktır. Bu durum veri toplama aşamasında gönüllü katılım gösteren ve göstermeyen okul türlerindeki farklılıktan kaynaklanmaktadır. 10 ve 11 yaş grubu katılımcılar ilkokul seviyesinde; 12, 13 ve 14 yaş grubu katılımcllar ise ilköğretim ikinci kademe ve/veya ortaokul seviyesinde eğitim veren okullarda eğitim öğretimine devam eden öğrencilerdir. Bu sonuç göstermektedir ki ilkokul seviyesindeki okullar, ilköğretim ikinci kademe ve/veya ortaokul seviyesindeki okullara göre daha fazla gönüllü katılım göstermiştir.

Tablo 4'e göre araştırmaya katılan ön ergenlerin annelerinin 158'i ilköğretim, 161'i lise, 237'si ön lisans/lisans ve $87^{\prime}$ si lisansüstü düzeyinde eğitime sahiptir. Araştırmaya katılan ön ergenlerin annelerinin yaklaşık \%50'si $(\% 49,6)$ ilköğretim ve lise düzeyinde eğitime sahipken, yaklaşık $\% 37$ 'si ön lisans/lisans düzeyinde, yaklaşı \%14'ü ise lisansüstü düzeyinde eğitime sahiptir. Aynı tabloda katılımcıların babalarının eğitim durumu görülmektedir. Buna göre katılımcı ön 
ergenlerin babalarını 92'si ilköğretim, 168'i lise, 271'i ön lisans/lisans ve 114'ü lisansüstü düzeyinde eğitime sahiptir. Araştırmaya katılan ön ergenlerin babalarının yaklaşık $\% 40^{\prime} 1(\% 40,3)$ ilköğretim ve lise düzeyinde eğitime sahipken, yaklaşık \%42'si ön lisans/lisans düzeyinde, yaklaşık \%18'ü ise lisansüstü düzeyinde eğitime sahiptir. Bu sonuçlara göre araştırmaya katılan ön ergenlerin babalarının eğitim düzeyinin annelerine göre daha yüksek olduğunu söylemek mümkündür.

Tablo 3. Araştırmaya Katılan Ön Ergenlerin Yaş İtibariyle Dağılımları

\begin{tabular}{lcc}
\hline Yaş & S1kl1k & $\mathbf{( \% )}$ \\
\hline 10 & 276 & 42,7 \\
11 & 228 & 35,2 \\
12 & 47 & 7,3 \\
13 & 50 & 7,7 \\
14 & 46 & 7,1 \\
Toplam & $\mathbf{6 4 7}$ & $\mathbf{1 0 0 , 0}$ \\
\hline
\end{tabular}

Tablo 4. Araştırmaya Katılan Ön Ergenlerin Ebeveynlerinin Eğitim Durumları İtibariyle Dağılımları

\begin{tabular}{lcc}
\hline Annenizin Eğitim Durumu & S1klık & $\mathbf{( \% )}$ \\
\hline İlköğretim & 158 & 24,6 \\
Lise & 161 & 25,0 \\
Ön Lisans/Lisans & 237 & 36,9 \\
Lisansüstü & 87 & 13,5 \\
Toplam & $\mathbf{6 4 3}$ & $\mathbf{1 0 0 , 0}$ \\
\hline Babanızın Eğitim Durumu & S1kl1k & $\mathbf{( \% )}$ \\
\hline İlköğretim & 92 & 14,3 \\
Lise & 168 & 26,0 \\
Ön Lisans/Lisans & 271 & 42,0 \\
Lisansüstü & 114 & 17,7 \\
Toplam & $\mathbf{6 4 5}$ & $\mathbf{1 0 0 , 0}$ \\
\hline
\end{tabular}

Araştırmaya katılan ön ergenlerin ebeveynlerinin meslekleri Tablo 5'te verilmiştir. Bu araştırma sorusu katılımcılara açık uçlu soru şeklinde sorulmuş, cevapların sınıflandırılmasında TUIKK tarafından yayınlanan uluslararası meslek sınıflandırılması (http://www.tuik.gov.tr) ayrımı kullanılmıştır. Bu ayrıma ilave olarak katılımcıların verdiği cevaplar doğrultusunda emekli, ev hanımı ve çalışmıyor maddeleri de sınıflandırmaya dahil edilmiştir.

Araştırmaya katılan katılımcıların ebeveynlerinin meslek dağılımı değerlendirilecek olursa; katılımcların annelerinin 281'i ev hanımı, 157'si profesyonel meslek mensubu, 81'i hizmet ve satış elemanı, 16'sı teknisyen, tekniker veya yardımcı profesyonel meslek mensubu, 7'si nitelik gerektirmeyen işlerde çalışan ve silahlı kuvvetler mensubu, 6'sı emekli ve 2'si yöneticidir. Bu sonuçlara göre, katılımcıların annelerinin yarısına yakını $(\% 44,2)$ ev hanımıdır. Yaklaşık $\% 25$ 'i ise profesyonel meslek mensubudur.

Araştırmaya katılanların babalarının mesleklerine ilişkin cevaplarına göre; 204'ü hizmet ve satış elemanı, 151'i profesyonel meslek mensubu, 107'si büro hizmetlerinde çalışan eleman, 48', i silahlı 
kuvvetleri mensubu, 31'i nitelik gerektirmeyen işlerde çalışan, 27'si tesis ve makine operatörü/ montajcı, 25'i emekli, 19'u teknisyen, tekniker veya yardımcı profesyonel meslek mensubu, 9'u nitelikli tarım, ormancılık ve su ürünleri çalışanı, 5'i sanatkârlar ve ilgili işlerde çalışan, 1'i yönetici ve 4'ü de çalışmıyor. Dağılıma baktığımızda, babaların yaklaşık \%32'si hizmet ve satış elemanı, \%23'ü profesyonel meslek mensubu, \%17'si büro hizmetlerinde çalışmaktadır. Geri kalan meslek gruplarında çalışan babaların oranı \%7'yi geçmemektedir. Annelerin yarısına yakını çalışmıyor iken; babaların yaklaşık \%45'i geliri yüksek işlerde çalışmakta; \%95'i aktif olarak iş hayatına devam etmektedir. Bu sonuca göre araştırmaya katılanların ailelerinde gelir sağlayan kişiler büyük oranda babalardır.

Tablo 5. Araştırmaya Katılan Ön Ergenlerin Ebeveynlerinin Meslekleri İtibariyle Dağılımları

\begin{tabular}{|c|c|c|}
\hline Annenizin Mesleği & Siklık & $(\%)$ \\
\hline Yöneticiler & 2 & 0,3 \\
\hline Profesyonel Meslek Mensupları & 157 & 24,7 \\
\hline Teknisyenler, Teknikerler ve Yardımcı & 16 & 2,5 \\
\hline \multicolumn{3}{|l|}{ Profesyonel Meslek Mensuplar1 } \\
\hline Büro Hizmetlerinde Çalışan Elemanlar & 79 & 12,4 \\
\hline Hizmet ve Satış Elemanları & 81 & 12,7 \\
\hline Nitelik Gerektirmeyen İşlerde & 7 & 1,1 \\
\hline \multicolumn{3}{|l|}{ Çalışanlar } \\
\hline Silahlı Kuvvetler Mensupları & 7 & 1,1 \\
\hline Emekli & 6 & 0,9 \\
\hline Ev Hanımı & 281 & 44,2 \\
\hline Toplam & 636 & 100,0 \\
\hline Babanızın Mesleği & Siklık & $(\%)$ \\
\hline Yöneticiler & 1 & 0,2 \\
\hline Profesyonel Meslek Mensupları & 151 & 23,9 \\
\hline $\begin{array}{l}\text { Teknisyenler, Teknikerler ve Yardımcı } \\
\text { Profesyonel Meslek Mensupları }\end{array}$ & 19 & 3,0 \\
\hline Büro Hizmetlerinde Çalışan Elemanlar & 107 & 17,0 \\
\hline Hizmet ve Satış Elemanları & 204 & 32,3 \\
\hline $\begin{array}{l}\text { Nitelikli Tarım, Ormancılık ve Su } \\
\text { Ürünleri Çalışanları }\end{array}$ & 9 & 1,4 \\
\hline Sanatkârlar ve İlgili İşlerde Çalışanlar & 5 & 0,8 \\
\hline $\begin{array}{l}\text { Tesis ve Makine Operatörleri ile } \\
\text { Montajcılar }\end{array}$ & 27 & 4,3 \\
\hline $\begin{array}{l}\text { Nitelik Gerektirmeyen İşlerde } \\
\text { Çalışanlar }\end{array}$ & 31 & 4,9 \\
\hline Silahlı Kuvvetler Mensupları & 48 & 7,6 \\
\hline Emekli & 25 & 4,0 \\
\hline Çalışmiyor & 4 & 0,6 \\
\hline Toplam & 631 & 100,0 \\
\hline
\end{tabular}

Tablo 6'ya göre katılımcıların ailelerinin gelir durumlarına ilişkin sonuçlara bakıldığında, 14 ailenin düşük, 491 ailenin orta ve 140 ailenin gelir durumunun yüksek olduğu görülmektedir. Orta gelir düzeyine sahip ailelerin toplamdaki oranı yaklaşık $\% 76$ ' dır. Katılımcıların sadece $\% 2$ 'si düşük gelir düzeyine sahiptir. 
Tablo 6. Araştırmaya Katılan Ön Ergenlerin 'Ailelerinin Gelir Durumları' İtibariyle Dağglımları

\begin{tabular}{lcc}
\hline Ailenizin Gelir Durumu & S1klık & $\mathbf{( \% )}$ \\
\hline Düşük & 14 & 2,2 \\
Orta & 491 & 76,1 \\
Yüksek & 140 & 21,7 \\
Toplam & $\mathbf{6 4 5}$ & $\mathbf{1 0 0 , 0}$ \\
\hline
\end{tabular}

Tablo 7. Araştırmaya Katılan Ön Ergenlerin Okudukları Okul Türleri İtibariyle Dağılımları

\begin{tabular}{lcc}
\hline \multicolumn{1}{c}{ Okuduğunuz Okulun Türü } & S1klık & $\mathbf{( \% )}$ \\
\hline Özel & 198 & 30,6 \\
Devlet & 449 & 69,4 \\
Toplam & $\mathbf{6 4 7}$ & $\mathbf{1 0 0 , 0}$ \\
\hline
\end{tabular}

Tablo 7' de araştırmaya katılan ön ergenlerin eğitim öğretime devam ettikleri okul türlerine ilişkin dağılım gösterilmiştir. Buna göre katılımcıların 198'i özel okula devam ederken, 449'u devlet okulunda eğitim öğretimine devam etmektedir. Araştırma kapsamında Çanakkale ili merkez ilçesinde 26 devlet ve 3 özel okulda anket uygulaması yapılmıştır. Toplamda 29 okul içinde devlet okullarının oranı yaklaşık \%90 iken araştırma verilerine göre devlet okuluna devam eden katılımcıların oranı yaklaşık \%70'tir. Bu sonuç ankete katılım gösteren devlet okulu oranının özel okullara göre daha düşük olduğunu göstermektedir. Veri gizliliğinin sağlanması açısından katılımcllara doğrudan okul ismi sorulmamıştır.

Tablo 8. Katılımcıların Hayranı Olduğu Ünlülere İlişkin Dağılım (1)

\begin{tabular}{|c|c|c|c|c|c|c|}
\hline \multirow{2}{*}{$\begin{array}{l}\text { Hayranı olduğunuz } 3 \text { ünlünün } \\
\text { isimlerini 1.En çok, 2. Çok ve } 3 . \\
\text { En az olacak şekilde sıralayınız }\end{array}$} & \multicolumn{2}{|c|}{ 1. EN ÇOK } & \multicolumn{2}{|c|}{ 2. ÇOK } & \multicolumn{2}{|c|}{ 3. EN AZ } \\
\hline & Siklık & $(\%)$ & Siklık & $(\%)$ & Siklık & $(\%)$ \\
\hline Müzisyen/Şarkıc1/Müzik Grubu & 226 & 34,9 & 241 & 45,6 & 226 & 47,1 \\
\hline Sporcu & 99 & 15,3 & 98 & 18,5 & 87 & 18,1 \\
\hline Youtuber/Influencer/Vlogger & 96 & 14,8 & 81 & 15,3 & 79 & 16,5 \\
\hline Oyuncu & 87 & 13,4 & 73 & 13,8 & 50 & 10,4 \\
\hline Tarihi kişilik & 32 & 4,9 & 8 & 1,5 & 9 & 1,9 \\
\hline Bilim İnsanı & 8 & 1,2 & 4 & 0,8 & 4 & 0,8 \\
\hline İş İnsanı/Siyasetçi & 1 & 0,2 & 2 & 0,4 & 8 & 1,7 \\
\hline Diğer & 23 & 3,6 & 22 & 4,2 & 17 & 3,5 \\
\hline Toplam & 572 & 100 & 529 & 100 & 480 & 100 \\
\hline
\end{tabular}

Araştırmaya katılan ön ergenlere, hayranı oldukları ünlülere ilişkin iki soru yönetilmiş, 75 katılımcı 'yok' cevabını vermiştir. Geriye kalan 572 katılımcının verdiği cevaplara ait bulgular Tablo 8' deki gibidir. Tablodaki sonuçlara göre, katılımcıların en çok beğendiği ünlüler müzisyen, şarkıcı ve müzik gruplarından $(\% 34,9)$ oluşmaktadır. En çok hayranı olunan ikinci grup sporcular $(\% 15,4)$ üçüncü grup ise youtuber, influencer ve vlogger ünlüleri $(\% 14,8)$ bulunmaktadır. Katılımcıların en çok hayranı olduğu Müzisyen/Şarkıcı/Müzik Grubu 'Hadise' ve 'Murat Boz', sporcular 'Ronaldo' ve 'Neymar', Youtuber/Influencer/Vlogger 'Enes Batur' ve 'Duygu Köseoğlu' olarak belirtilmiştir. Katılımcların yaklaşık \%5'i en çok hayranı olduğu ünlü bir bilim insanı (Eistein (3), Stephen Hawking (2), Yuri Gagarin (1), Neil Amstrong (2)) olduğunu söylemiştir. 
Katılımcların bu ayrımlar dışında vermiş oldukları cevaplar diğer seçeneğinde gösterilmiştir. Bu seçeneğe dahil edilen cevaplar; komedyenler, yazarlar, survivor yarışmacıları, manken ve modeller ile medyatik diğer ünlülerden oluşmaktadır. Bu seçenekte en çok belirtilen ünlü isim 'Cem Yılmaz' ve 'Turabi' olmuştur. Bu sonuçlar göstermektedir ki 10-14 yaş grubundaki bu ön ergenler çoğunlukla televizyon ve internet aracılığıyla tanıdıkları ünlülere hayranlık duymaktadırlar.

Tablo 9. Katılımcıların Hayranı Olduğu Ünlülere İlişkin Dağılım (2)

\begin{tabular}{|c|c|c|c|c|c|c|}
\hline \multirow{2}{*}{$\begin{array}{l}\text { Hayranı olduğunuz kişilerden } \\
\text { etkilenerek satın aldığınız } \\
\text { ürünler nelerdir? Üçünü } \\
\text { sıralayınız }\end{array}$} & \multicolumn{2}{|c|}{ 1. TERCIH } & \multicolumn{2}{|c|}{ 2. TERCIH } & \multicolumn{2}{|c|}{ 3. TERCIH } \\
\hline & Siklık & $(\%)$ & Siklık & $(\%)$ & Siklık & $(\%)$ \\
\hline Giysi/Ayakkabı & 82 & 27,5 & 65 & 28,6 & 36 & 24,8 \\
\hline Spor Malzemesi & 55 & 18,5 & 32 & 14,1 & 17 & 11,7 \\
\hline Takı/Aksesuar & 45 & 15,1 & 44 & 19,4 & 39 & 26,9 \\
\hline Oyuncak & 24 & 8,1 & 18 & 7,9 & 3 & 2,1 \\
\hline Kitap/Kırtasiye & 22 & 7,4 & 24 & 10,6 & 17 & 11,7 \\
\hline Kozmetik Malzemesi & 12 & 4 & 7 & 3,1 & 6 & 4,1 \\
\hline Teknolojik Ürün/Aksesuarı & 10 & 3,4 & 5 & 2,2 & 9 & 6,2 \\
\hline Cd/Albüm & 9 & 3 & 4 & 1,8 & 2 & 1,4 \\
\hline Yiyecek/İçecek & 8 & 2,7 & 6 & 2,6 & 2 & 1,4 \\
\hline Bilgisayar & 7 & 2,3 & 3 & 1,3 & 3 & 2,1 \\
\hline Telefon & 5 & 1,7 & 3 & 1,3 & 2 & 1,4 \\
\hline Bilgisayar Oyunu & 5 & 1,7 & 7 & 3,1 & 2 & 1,4 \\
\hline Diğer & 14 & 4,7 & 9 & 4,0 & 7 & 4,8 \\
\hline Toplam & 298 & 100 & 227 & 100 & 145 & 100 \\
\hline
\end{tabular}

Tablo 9'da ise katılımcılara sorulan 'Hayranı olduğunuz kişilerden etkilenerek satın aldığınız ürünler nelerdir? Üçünü sıralayınız' sorusuna yanıtlar yer almaktadır. Katılımcıların 349'u 'Yok' yanıtını vermiştir. Geriye kalan 298 katılımcının verdikleri yanıtlara ilişkin bulgular yer almaktadır. Buna göre katılımcıların hayranı olduğu kişilerden etkilenerek satın aldığı ürünlerin başında giysi/ayakkabı, spor malzemeleri ve takı/aksesuar gelmektedir. Katılımcların hayranı olduğu kişilerden etkilenerek satın aldığı ürünlerde ikinci sırada tercih ettiği ürünler yine giysi/ayakkabı, takı/aksesuar ve spor malzemeleri olarak sıralanmaktadır. Katılımcıların üçüncü sırada tercih ettiği ürünler ise takı/aksesuar, giysi/ayakkabı ile spor malzemesi ve kitap/kırtasiye olarak siralanmaktadır. Bu sorunun birinci tercih kısmına katılımciların \%46's1 yanıt verirken, ikinci tercih kısmına \%35'i ve üçüncü tercih kısmına ise \%22'si yanıt vermiştir. Diğer seçeneğinden belirtilen ürünler ise, bardak/kupa, yastık/nevresim takımı, poster/broşür, gitar, bağlama ve evcil hayvan şeklinde belirtilen ürünlerden oluşmaktadır. Bu sonuçlara göre katılımcı ön ergenlerin hayranı olduğu ünlülerden en çok etkilendiği ürün grubu giysi, ayakkabı, çanta, bileklik, forma, krampon gibi ürünlerdir.

\section{Geçerlilik Analizi}

Çalışmada kullanılan ölçeklerin geçerliliğini test etmek bunun yanında çalışma çerçevesinde kullanılan değişkenleri oluşturan faktörlerin neler olduğunu ve bu faktörlerden her birinin 
değişkenleri açıklama derecesini görmek amacıyla açıklayıcı faktör analizi yapılmıştır. Analiz sonuçlarına göre değişkenlere ait faktör analizi sonuçları Tablo $13^{\prime}$ de verilmiştir.

Tablo 10. Sembolik Tüketim Değişkenine İlişkin Açıklayıcı Faktör Analizi Sonuçları

\begin{tabular}{lc}
\hline İfadeler & Faktör Yükleri \\
\hline Bu ürünü kullanmak benim değerli ve özel biri olarak görünmeme & 0,732 \\
yardımcı olur. & 0,705 \\
Bu ürünü kullanmak toplum içerisinde bana saygınlık kazandırır. & 0,689 \\
$\begin{array}{l}\text { Bu ürünü kullanmak insanların bana güven duymalarına yardımcı olur. } \\
\text { Insanlar üzerimde bu ürüne ait isim ya da logoları gördüklerinde } \\
\text { toplumdaki yerim hakkında fikir sahibi olurlar. }\end{array}$ & 0,686 \\
Bu ürün sosyal statüme (toplum içindeki konumuma) uygundur. & 0,682 \\
Bu ürünü kullanarak toplum içinde kendimi daha rahat ve güvenli & 0,679 \\
hissediyorum. & \\
Bu ürünü kullanan diğer kişilerle aramda ortak yönler olduğunu & 0,649 \\
düşünüyorum. & 0,647 \\
Bu ürünü kullanarak başarılı biri olduğumu gösterebilirim. & 0,645 \\
Bu ürünü kullanmak beni olmak istediğim biri gibi gösterir. & 0,625 \\
Bu ürün manevi değerlerime uygundur. & 0,614 \\
Bu ürünü kullanmak zengin görünmemi sağlar. & 0,613 \\
Bu ürünün benim imajıma uygun olduğunu düşünüyorum. & 0,613 \\
Bu ürünü kullanarak modayı takip etmiş olurum. & 0,598 \\
Bu ürünün tarzımı yansıttığını düşünüyorum. & 0,598 \\
Arkadaşlarım da bu ürünü beğenir. & 0,587 \\
Bu ürün kişiliğime uygundur. & 0,586 \\
Ailemdeki diğer kişiler de bu ürünü beğenir. & 0,583 \\
Bu ürün ünlü kişilerin kullandığı bir üründür. & $\mathbf{\% 5 2 , 6 3 9}$ \\
\hline Toplam Açılanan Varyans & $\mathbf{0 , 9 3 3}$ \\
KMO Örneklem Yeterliliği & $\mathbf{5 3 0 5 , 4 8 4}$ \\
\hline & $\mathbf{1 5 3}$ \\
Bartlett Küresellik Testi & $\mathbf{0 0 0}$ \\
\hline
\end{tabular}

Sembolik tüketim ölçeğinde 18 ifade yer almaktadır. Tablo 10'da görüldüğüü üzere, yapılan faktör analizi sonucunda tek bir faktör elde edilmiştir. Bu tek faktör varyansın \%52,639'unu temsil etmektedir. Yapıya sayısal anlamda bakıldı̆̆ında örneklem yeterliliğini ifade eden KMO değerinin kabul edilebilir alt değer olan 0,50'nin (Kalaycı, 2006: 322) üzerinde olduğu ve madde yapısından anlamlı faktörler çıkartılabileceğini gösteren Barlett küresellik testinin ise anlamlı olduğu saptanmıştır. Maddelerin faktör yüklerinin \%58 ile \%73 arasında olduğu ve kabul edilebilir düzeyde (Özdamar, 2010:227) oldukları görülmektedir.

Ünlü hayranlığı ölçeğinde 5 ifade yer almaktadır. Tablo 11'de görüldüğü üzere, yapılan faktör analizi sonucunda tek bir faktör elde edilmiştir. Bu tek faktör varyansın \%52,023'ünü temsil etmektedir. Yapıya sayısal anlamda bakıldı̆̆ında örneklem yeterliliğini ifade eden KMO değerinin kabul edilebilir alt değer olan 0,50'nin üzerinde olduğu ve madde yapısından anlamlı faktörler çıkartılabileceğini gösteren Barlett küresellik testinin ise anlamlı olduğu saptanmıştır. 
Maddelerin faktör yüklerinin \%53 ile \%88 arasında olduğu ve kabul edilebilir düzeyde oldukları görülmektedir.

Tablo 11. Ünlü Hayranlığı Değişkenine İlişkin Açıklayıcı Faktör Analizi Sonuçları

\begin{tabular}{lc}
\hline İfadeler & $\begin{array}{l}\text { Faktör } \\
\text { Yükleri }\end{array}$ \\
\hline $\begin{array}{l}\text { Fiyatları ne kadar yüksek olursa olsun hayranı olduğum kişilerin kullandığıı, } \\
\text { tanıttığı ürünleri satın almak isterim. }\end{array}$ & 0,815 \\
$\begin{array}{l}\text { Hayranı olduğum kişilerin alışveriş yaptıkları mağazalardan alışveriş̧ yapmak } \\
\text { isterim. }\end{array}$ & 0,796 \\
$\begin{array}{l}\text { Sosyal medya ortamında popüler olan ürün ve markaları satın almayı tercih } \\
\text { ederim. }\end{array}$ & 0,729 \\
$\begin{array}{l}\text { Moda olan mağazalardan alışveriş yapmak isterim. } \\
\text { Alışveriş yaptığım mağaza tercihlerimde hayranı olduğum ünlülerin etkisi } \\
\text { yoktur. }\end{array}$ & 0,665 \\
\hline $\begin{array}{l}\text { Toplam Açıklanan Varyans } \\
\text { KMO Örneklem Yeterliliği }\end{array}$ & 0,573 \\
\hline & $\mathbf{\% 5 2 , 0 2 3}$ \\
Bartlett Küresellik Testi & $\mathbf{0 , 7 7 8}$ \\
\hline
\end{tabular}

Tablo 12. Satın Alma Niyeti Değişkenine İlişkin Açıklayıcı Faktör Analizi Sonuçları

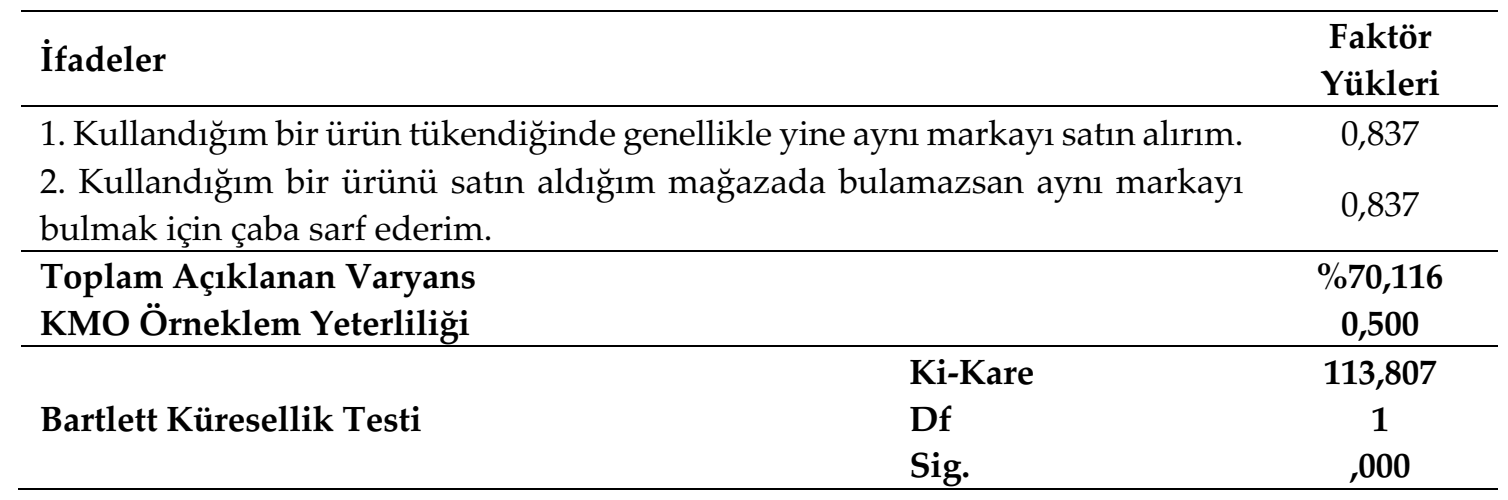

Satın alma niyeti ölçeğinde 2 ifade yer almaktadır. Tablo 12' de görüldüğü üzere, yapılan faktör analizi sonucunda tek bir faktör elde edilmiştir. Bu tek faktör varyansın \%70,116'sını temsil etmektedir. Yapıya sayısal anlamda bakıldı̆̆ında örneklem yeterliliğini ifade eden KMO değerinin kabul edilebilir alt değer olan 0,50 olduğu ve madde yapısından anlamlı faktörler çıkartılabileceğini gösteren Barlett küresellik testinin ise anlamlı olduğu saptanmıştır. Maddelerin faktör yüklerinin \%83 olduğu ve kabul edilebilir düzeyde oldukları görülmektedir.

\section{Güvenilirlik Analizi}

Çalışmanın güvenilirlik analizinde, araştırma modelinde yer alan üç değişkenin alfa katsayılarına bakılmıştır. Aşağıda araştırma değişkenlerine ilişkin madde-bütün (Item-Total) korelasyon değerleri ve Cronbach Alpha $(\alpha)$ katsayıları görülmektedir. 
Tablo 13. Sembolik Tüketim Değişkeni Güvenilirlik Analizi Sonuçları

\begin{tabular}{|c|c|c|}
\hline Değişkenler & $\begin{array}{l}\text { Madde-Bütün } \\
\text { Korelasyon } \\
\text { Değerleri }\end{array}$ & $\begin{array}{c}\text { Alfa } \\
\text { Değerleri }\end{array}$ \\
\hline Bu ürünün benim imajıma uygun olduğunu düşünüyorum. & 0,471 & 0,912 \\
\hline Bu ürünün tarzımı yansıttığını düşünüyorum. & 0,546 & 0,910 \\
\hline Bu ürün manevi değerlerime uygundur. & 0,569 & 0,909 \\
\hline Bu ürünü kullanmak beni olmak istediğim biri gibi gösterir. & 0,591 & 0,908 \\
\hline Bu ürün kişiliğime uygundur. & 0,532 & 0,910 \\
\hline Ailemdeki diğer kişiler de bu ürünü beğenir. & 0,528 & 0,910 \\
\hline Arkadaşlarım da bu ürünü beğenir. & 0,546 & 0,910 \\
\hline Bu ürün ünlü kişilerin kullandığı bir üründür. & 0,528 & 0,910 \\
\hline $\begin{array}{l}\mathrm{Bu} \text { ürünü kullanan diğer kişilerle aramda ortak yönler } \\
\text { olduğunu düşünüyorum. }\end{array}$ & 0,594 & 0,908 \\
\hline $\begin{array}{l}\text { Bu ürünü kullanarak toplum içinde kendimi daha rahat ve } \\
\text { güvenli hissediyorum. }\end{array}$ & 0,621 & 0,908 \\
\hline Bu ürünü kullanarak modayı takip etmiş olurum. & 0,556 & 0,909 \\
\hline $\begin{array}{l}\mathrm{Bu} \text { ürün sosyal statüme (toplum içindeki konumuma) } \\
\text { uygundur. }\end{array}$ & 0,628 & 0,907 \\
\hline $\begin{array}{l}\text { İnsanlar üzerimde bu ürüne ait isim ya da logoları } \\
\text { gördüklerinde toplumdaki yerim hakkında fikir sahibi } \\
\text { olurlar. }\end{array}$ & 0,629 & 0,907 \\
\hline $\begin{array}{l}\text { Bu ürünü kullanmak insanların bana güven duymalarına } \\
\text { yardımcı olur. }\end{array}$ & 0,631 & 0,907 \\
\hline $\begin{array}{l}\text { Bu ürünü kullanmak toplum içerisinde bana saygınlık } \\
\text { kazandırır. }\end{array}$ & 0,647 & 0,907 \\
\hline $\begin{array}{l}\text { Bu ürünü kullanmak benim değerli ve özel biri olarak } \\
\text { görünmeme yardımcı olur. }\end{array}$ & 0,680 & 0,906 \\
\hline Bu ürünü kullanmak zengin görünmemi sağlar. & 0,557 & 0,909 \\
\hline Bu ürünü kullanarak ile başarılı biri olduğumu gösterebilirim. & 0,587 & 0,909 \\
\hline Sembolik Tüketim Alfa Güvenilirlik Değeri & & 0,913 \\
\hline
\end{tabular}

Tablo $13^{\prime}$ de sembolik tüketim değişkenine ilişkin güvenilirlik analizi sonuçları verilmiştir. Değişkenlere ait madde bütün (Item-total) korelasyonları 0,471 ile 0,680 arasında değişen değerlerdedir. Buna göre Büyüköztürk (2005), Nakip (2006) ve Özdamar (2010)'in belirttiği 0,25 ve 0,30 değerlerinin altında bir değere sahip değildir ve dolayısıyla ölçeğin madde ile bütün arasındaki korelasyonu uygundur. Cronbach Alpha $(\alpha)$ değerleri ise 0,906 ve 0,912 arasındadır. 18 maddelik sembolik tüketim ölçeğinin tamamı için Cronbach Alpha $(\alpha)$ değeri 0,913 olarak hesaplanmıştır. Bu oran ölçeğin yüksek derecede güvenilir olduğunu göstermektedir (Kalayc1, 2006; İslamoğlu, 2009; Nakip, 2006). Bu nedenle çalışmada kullanılan sembolik tüketim ölçeklerinin güvenilir olduğu ifade edilebilmektedir.

Ünlü hayranlığı değişkenine ait madde bütün (Item-total) korelasyonları 0,393 ile 0,646 arasında değişen değerlerdedir. Cronbach Alpha $(\alpha)$ değerleri ise 0,680 ve 0,741 arasındadır. 5 maddelik ünlü hayranlığı ölçeğinin tamamı için Cronbach Alpha $(\alpha)$ değeri 0,764 olarak hesaplanmıştır. Bu oran ölçeğin oldukça güvenilir olduğunu göstermektedir. 
Tablo 14. Ünlü Hayranlığı Değişkeni İçin Güvenilirlik Analizi Sonuçları

\begin{tabular}{|c|c|c|}
\hline Değişkenler & $\begin{array}{c}\text { Madde-Bütün } \\
\text { Korelasyon } \\
\text { Değerleri }\end{array}$ & $\begin{array}{c}\text { Alfa } \\
\text { Değerleri }\end{array}$ \\
\hline $\begin{array}{l}\text { Hayranı olduğum kişilerin alışveriş yaptıkları mağazalardan } \\
\text { alışveriş yapmak isterim. }\end{array}$ & 0,627 & 0,686 \\
\hline $\begin{array}{l}\text { Fiyatları ne kadar yüksek olursa olsun hayranı olduğum } \\
\text { kişilerin kullandığı, tanıttığı ürünleri satın almak isterim. }\end{array}$ & 0,646 & 0,680 \\
\hline Moda olan mağazalardan alışveriş yapmak isterim. & 0,473 & 0,741 \\
\hline $\begin{array}{l}\text { Sosyal medya ortamında popüler olan ürün ve markaları satın } \\
\text { almayı tercih ederim. }\end{array}$ & 0,538 & 0,720 \\
\hline $\begin{array}{l}\text { Alışveriş yaptığım mağaza tercihlerimde hayranı olduğum } \\
\text { ünlülerin etkisi yoktur. }\end{array}$ & 0,393 & 0,769 \\
\hline Ünlü Hayranlığı Alfa Güvenilirlik Değeri & & 0,764 \\
\hline
\end{tabular}

Tablo 15. Satın Alma Niyeti Değişkeni Güvenilirlik Analizi Sonuçları

\begin{tabular}{lcc}
\hline Değişkenler & $\begin{array}{c}\text { Madde-Bütün } \\
\text { Korelasyon } \\
\text { Değerleri }\end{array}$ & $\begin{array}{c}\text { Alfa } \\
\text { Değerleri }\end{array}$ \\
\hline $\begin{array}{l}\text { Kullandığım bir ürün tükendiğinde genellikle yine aynı ürünü } \\
\text { satın alırım. }\end{array}$ & 0,618 & 0,907 \\
$\begin{array}{l}\text { Kullandığım bir ürünü satın aldığım mağazada bulamazsan } \\
\text { aynı ürünü bulmak için çaba sarf ederim. }\end{array}$ & 0,635 & 0,900 \\
\hline Satın Alma Niyeti Alfa Güvenilirlik Değeri & & $\mathbf{0 , 8 5 8}$ \\
\hline
\end{tabular}

Tablo 15 'de satın alma niyeti değişkenine ilişkin güvenilirlik analizi sonuçları verilmiştir. Değişkenlere ait madde bütün (Item-total) korelasyonları 0,618 ve 0,635 olarak hesaplanmıştır. Bu sonuçlar Büyüköztürk (2005), Nakip (2006) ve Özdamar (2010)'in belirttiği 0,25 ve 0,30 değerlerinin altında bir değere sahip değildir ve dolayısıyla ölçeğin soru ile bütün arasındaki korelasyonu uygundur. 2 maddelik satın alma niyeti ölçeğinin tamamı için Cronbach Alpha $(\alpha)$ değeri 0,858 olarak hesaplanmıştır. Bu oran, ölçeğin yüksek derecede güvenilir olduğunu göstermektedir.

\section{Regresyon Analizi ve Hipotez Testleri}

Sembolik tüketimin satın alma niyeti üzerine etkisinde ünlü hayranlığının aracılık etkisini belirlemek amacıyla Baron ve Kenny (1986: 1177) tarafından önerilen üç aşamalı regresyon analizi yapılmıştır. Bu durumda ilk aşamada bağımsız değişken (sembolik tüketim) ile aracılık etkisine sahip olup olmadığı tespit edilecek olan değişken (ünlü hayranlığı) arasında bir regresyon analizinin yapılması ve anlamlı bir etkinin olup olmadığının belirlenmesi gerekmektedir. İkinci aşamada yine bağımsız değişken (sembolik tüketim) ile bağımlı değişken (satın alma niyeti) arasındaki sebep sonuç ilişkisi araştırılmalıdır. Üçüncü aşamada ise aracı değişken (ünlü hayranlığı) ile bağımlı değişken (satın alma niyeti) arasında bağımsız değişkenin (sembolik tüketim) kontrol edildiği bir regresyon analizi yapılması gerekmektedir. Bu analizler sonucunda, bir aracılık etkisinin olup olmadığını ortaya koyabilmek için ikinci aşamada bağımsız değişkenin (sembolik tüketim) bağımlı değişken (satın alma niyeti) üzerindeki etkisinin tamamen ortadan 
kalkıp kalkmadığına bakılması gerekir. Bu durumda etkide bir düşme görülüyor ve ilişki anlamlılı̆̆ını sürdürüyorsa "kısmi aracılık etkisi"nden; etki tamamen ortadan kalkıyorsa "tam aracılık etkisi"nden söz etmek mümkündür. Ancak bu aşamada aracı değişken ile bağımlı değişken arasındaki ilişkinin anlamlılık düzeyini koruması gerekmektedir (Baron ve Kenny, 1986: 1177).

\section{Sembolik Tüketim ile Ünlü Hayranlığı Arasındaki İlişkinin İncelenmesi}

İlk aşamada bağımsız değişken (sembolik tüketim) ile aracılık etkisine sahip olup olmadığı tespit edilecek olan değişken (ünlü hayranlığı) arasında bir regresyon analizinin yapılması ve anlamlı bir ilişkinin olup olmadığının belirlenmesi gerekmektedir. Ünlü hayranlığı aracı değişkeni için kurulan yapısal eşitlik modellemesine ait sonuçlar aşağıda verilmiştir.

$\mathbf{H}_{2 a}$ : Sembolik tüketimin ünlü hayranlığı üzerinde anlamlı bir etkisi vardır.

Tablo 16. Kurulan YEM Modeli İçin Uyum Kriterlerine Ait Değerler

\begin{tabular}{ccccc}
\hline $\begin{array}{c}\text { UYUM } \\
\text { KRITERLERI }\end{array}$ & $\begin{array}{c}\text { MÜKEMMEL } \\
\text { UYUM }\end{array}$ & $\begin{array}{c}\text { KABUL } \\
\text { EDİLEBİLİ } \\
\text { UYUM }\end{array}$ & $\begin{array}{c}\text { GELIŞTİIILEN } \\
\text { ÖLÇEĞE AİT } \\
\text { DEĞERLER }\end{array}$ & UYUM \\
\hline$\chi 2 / \mathrm{sd}$ & $\leq 3$ & $\leq 5$ & 4.784 & Kabul Edilebilir Uyum \\
\hline RMSEA & $0<$ RMSEA $<0.05$ & $0.05 \leq$ RMSEA $\leq 0.10$ & 0.077 & Kabul Edilebilir Uyum \\
\hline SRMR & $0<$ SRMR $<0.05$ & $0.05 \leq$ SRMR $\leq 0.10$ & 0.071 & Kabul Edilebilir Uyum \\
\hline
\end{tabular}

Kaynak: Schermelleh-Engel vd., 2003: 52.

Tablo 16 incelendiğinde kurulan YEM modeline ilişkin uyum indeksleri değerleri incelendiğinde RMSEA değerinin kabul edilebilir uyum indeksi arasında olduğu (RMSEA= 0,077, $0.05 \leq$ RMSEA $\leq 0.10$ ), SRMR değerinin kabul edilebilir uyum indeksi arasında olduğu (SRMR= $0,071,0.05 \leq \mathrm{SRMR} \leq 0.10)$ görülmektedir.

Kurulan YEM modeli sonucunda modelin uyum indekslerinin kabul edilebilir uyum değerleri arasındaki olduğu $(\chi 2 / \mathrm{df}=4,784<5)$ belirlenmiştir.

Tablo 17. Sembolik Tüketim ile Ünlü Hayranlığı İlişkisine Yönelik Kurulan Modelin Standartlaştırılmış Parametre Tahmini, t istatistiği ve Hipotez

\begin{tabular}{ccccc}
\hline Hipotezler & Yollar & $\begin{array}{c}\text { Standartlaştırılmış } \\
\text { Parametre } \\
\text { Tahmini }\end{array}$ & t İstatistiği & SONUÇ \\
\hline $\mathrm{H}_{2 \mathrm{a}}$ & $\mathrm{SEM} \rightarrow$ UNLU & 0,51 & 10,63 & DOĞRULANDI \\
\hline
\end{tabular}

Tablo 17 incelendiğinde sembolik tüketim ile ünlü hayranlı̆̆ arasında kurulan hipotezin istatistiksel açıdan doğrulandığı belirlenmiştir. Kurulan YEM modeline ait regresyon modeli sonucu aşağıda verilmiştir:

Modelı:UNLU=0,51*SEM 


\section{Sembolik Tüketim ile Satın Alma Niyeti Arasındaki İlişkinin İncelenmesi}

İkinci aşamada sembolik tüketim ile satın alma niyeti arasındaki etkiyi belirlemek için kurulan yapısal eşitlik modellemesine ait sonuçlar Tablo 18'de verilmiştir.

H1: Sembolik tüketimin satın alma niyeti üzerinde anlamlı etkisi vardır.

Tablo 18. Kurulan YEM Modeli İçin Uyum Kriterlerine Ait Değerler

\begin{tabular}{ccccc}
\hline $\begin{array}{c}\text { UYUM } \\
\text { KRITERLERI }\end{array}$ & $\begin{array}{c}\text { MÜKEMMEL } \\
\text { UYUM }\end{array}$ & $\begin{array}{c}\text { KABUL } \\
\text { EDİLEBILIR } \\
\text { UYUM }\end{array}$ & $\begin{array}{c}\text { GELİSTİRİEN } \\
\text { ÖLÇEĞE Aİ } \\
\text { DEĞERLER }\end{array}$ & UYUM \\
\hline RMSEA & $0<$ RMSEA $<0.05$ & $0.05 \leq$ RMSEA $\leq 0.10$ & 0.077 & $\begin{array}{c}\text { Kabul Edilebilir } \\
\text { Uyum }\end{array}$ \\
\hline SRMR & $0<$ SRMR $<0.05$ & $0.05 \leq$ SRMR $\leq 0.10$ & 0.064 & $\begin{array}{c}\text { Kabul Edilebilir } \\
\text { Uyum }\end{array}$ \\
\hline CFI & $0.95 \leq \mathrm{CFI} \leq 1$ & $0.90 \leq \mathrm{CFI} \leq 0.95$ & 0.900 & $\begin{array}{c}\text { Kabul Edilebilir } \\
\text { Uyum }\end{array}$ \\
\hline GFI & $0.95 \leq \mathrm{GFI} \leq 1$ & $0.90 \leq \mathrm{GFI} \leq 0.95$ & 0.900 & $\begin{array}{c}\text { Kabul Edilebilir } \\
\text { Uyum }\end{array}$ \\
\hline AGFI & $0.90 \leq \mathrm{AGFI} \leq 1$ & $0.85 \leq \mathrm{AGFI} \leq 0.90$ & 0.860 & $\begin{array}{c}\text { Kabul Edilebilir } \\
\text { Uyum }\end{array}$ \\
\hline IFI & $0.95 \leq \mathrm{IFI} \leq 1$ & $0.90 \leq \mathrm{AGFI} \leq 0.95$ & 0.900 & $\begin{array}{c}\text { Kabul Edilebilir } \\
\text { Uyum }\end{array}$ \\
\hline
\end{tabular}

Kaynak: Schermelleh-Engel vd., 2003: 52.

Tablo 18 incelendiğinde kurulan YEM modeline ilişkin uyum indeksleri değerleri incelendiğinde RMSEA değerinin kabul edilebilir uyum indeksi arasında olduğu (RMSEA= 0,071, $0.05 \leq$ RMSEA $\leq 0.10$ ), SRMR değerinin kabul edilebilir uyum indeksi arasında olduğu (SRMR= 0,061, 0.05 $\leq$ SRMR $\leq 0.10)$, CFI değerinin $(\mathrm{CFI}=0,900,0.90 \leq \mathrm{CFI} \leq 0.95)$ kabul edilebilir uyum indeksi arasında olduğu, GFI değerinin (GFI=0,900, 0.90 $\leq \mathrm{GFI} \leq 0,95)$ kabul edilebilir uyum indeksi arasında olduğu, AGFI değerinin (AGFI=0,850, 0.85 $\leq$ AGFI $\leq 0.90$ ) ve IFI değerinin (IFI= 0,910, $0.90 \leq \mathrm{IFI} \leq 0.95$ ) kabul edilebilir uyum indeksi arasında olduğu görülmektedir.

Kurulan YEM modeli sonucunda modelin uyum indekslerinin kabul edilebilir uyum değerleri arasındaki olduğu $(\chi 2 / \mathrm{df}=4,846<5)$ belirlenmiştir.

Tablo 19. Sembolik Tüketim ile Satın Alma Niyeti İlişkisine Yönelik Kurulan Modelin Standartlaştııılmış Parametre Tahmini, t istatistiği ve Hipotez

\begin{tabular}{ccccc}
\hline Hipotezler & Yollar & $\begin{array}{c}\text { Standartlaştırılmış } \\
\text { Parametre } \\
\text { Tahmini }\end{array}$ & t İstatistiği & SONUÇ \\
\hline $\mathrm{H}_{1}$ & SEM $\rightarrow$ SAN & 0,44 & 6,27 & DOĞRULANDI \\
\hline
\end{tabular}

Tablo 19 incelendiğinde sembolik tüketim ile satın alma niyeti arasında kurulan hipotezin istatistiksel açıdan doğrulandığı belirlenmiştir. Kurulan YEM modeline ait regresyon modeli sonucu aşağıda verilmiştir:

Model2: $\mathrm{SAN}=0,44^{*} \mathrm{SEM}$ 


\section{Sembolik Tüketim ile Satın Alma Niyeti Arasındaki İlişkide Ünlü Hayranlı̆̆ının Aracilık Etkisinin İncelenmesi}

Üçüncü aşamada aracı değişken (ünlü hayranlığı) ile bağımlı değişken (satın alma niyeti) arasında bağımsız değişkenin (sembolik tüketimin) kontrol edildiği bir regresyon analizi yapılması ve anlamlı bir ilişkinin olup olmadığının belirlenmesi için kurulan yapısal eşitlik modellemesine ait sonuçlar aşağı da verilmiştir.

\section{Hipotez:}

$\mathbf{H}_{2 a}$ : Sembolik tüketimin ünlü hayranlığı üzerinde anlamlı bir etkisi vardır.

$\mathbf{H}_{2 b}$ : Ünlü hayranlığının satın alma niyeti üzerinde anlamlı bir etkisi vardır.

H1: Sembolik tüketimin satın alma niyeti üzerinde anlamlı bir etkisi vardır.

Tablo 20. Kurulan YEM Modeli İçin Uyum Kriterlerine Ait Değerler

\begin{tabular}{|c|c|c|c|c|}
\hline $\begin{array}{c}\text { UYUM } \\
\text { KRİTERLERİ }\end{array}$ & $\begin{array}{l}\text { MÜKEMMEL } \\
\text { UYUM }\end{array}$ & $\begin{array}{c}\text { KABUL } \\
\text { EDİLEBİLIR } \\
\text { UYUM }\end{array}$ & $\begin{array}{c}\text { GELIŞTİíLEN } \\
\text { ÖLÇEĞE AİT } \\
\text { DEĞERLER }\end{array}$ & UYUM \\
\hline$\chi 2 / s d$ & $\leq 3$ & $\leq 5$ & 4.840 & $\begin{array}{c}\text { Kabul Edilebilir } \\
\text { Uyum }\end{array}$ \\
\hline RMSEA & $0<$ RMSEA $<0.05$ & $0.05 \leq \mathrm{RMSEA} \leq 0.10$ & 0.077 & $\begin{array}{c}\text { Kabul Edilebilir } \\
\text { Uyum }\end{array}$ \\
\hline SRMR & $0<\mathrm{SRMR}<0.05$ & $0.05 \leq \mathrm{SRMR} \leq 0.10$ & 0.073 & $\begin{array}{c}\text { Kabul Edilebilir } \\
\text { Uyum }\end{array}$ \\
\hline
\end{tabular}

Kaynak: Schermelleh-Engel vd., 2003: 52.

Tablo 20 incelendiğinde kurulan YEM modeline ilişkin uyum indeksleri değerleri incelendiğinde RMSEA değerinin kabul edilebilir uyum indeksi arasında olduğu (RMSEA= 0,077, $0.05 \leq$ RMSEA $\leq 0.10$ ), SRMR değerinin kabul edilebilir uyum indeksi arasında olduğu (SRMR= $0,073,0.05 \leq \mathrm{SRMR} \leq 0.10$ ) görülmektedir.

Kurulan YEM modeli sonucunda modelin uyum indekslerinin kabul edilebilir uyum değerleri arasındaki olduğu $(\chi 2 / \mathrm{df}=4,840<5)$ belirlenmiştir.

Tablo 21. Aracılık İlişkisine Yönelik Kurulan Modelin Standartlaştırılmış Parametre Tahmini, t istatistiği ve Hipotez

\begin{tabular}{ccccc}
\hline Hipotezler & Yollar & $\begin{array}{c}\text { Standartlaştırılmış } \\
\text { Parametre } \\
\text { Tahmini }\end{array}$ & t İstatistiği & SONUÇ \\
\hline $\mathrm{H} 2_{\mathrm{a}}$ & $\mathrm{SEM} \rightarrow$ UNLU & 0,50 & 10,48 & DOĞRULANDI \\
\hline $\mathrm{H}_{2 \mathrm{~b}}$ & $\mathrm{UNLU} \rightarrow \mathrm{SAN}$ & 0,19 & 2,80 & DOĞRULANDI \\
\hline $\mathrm{H}_{1}$ & $\mathrm{SEM} \rightarrow \mathrm{SAN}$ & 0,33 & 4,66 & DOĞRULANDI \\
\hline
\end{tabular}

Tablo 21 incelendiğinde sembolik tüketim ile satın alma niyeti arasında kurulan, sembolik tüketim ile ünlü hayranlığı arasında kurulan ve ünlü hayranlığı ile satın alma niyeti arasında kurulan hipotezlerin istatistiksel açıdan doğrulandığı belirlenmiştir. Sembolik tüketim ile satın alma niyeti arasındaki ilişkide ünlü hayranlığı aracılık etkisini belirlemeye yönelik oluşturulan regresyon modeli Şekil 2' de verilmiştir. 


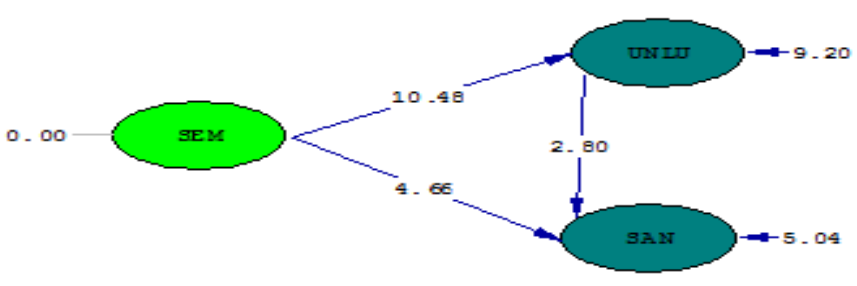

Şekil 2. Ünlü Hayranlığının Aracılık Etkisini Belirlemeye Yönelik Regresyon Modeli

Sembolik tüketim ile satın alma niyeti arasındaki ilişkide ünlü hayranlığının aracılık rolünün incelendiği regresyon analizi sonuçlarına göre ilk aşamada sembolik tüketimin bağımsız değişken ünlü hayranlığının bağımlı değişken olduğu bir regresyon analizi yapılmıştır (Model1). Oluşturulan modelde sembolik tüketim değişkeni aracı değişken olarak ele alınan ünlü hayranlığı değişkenindeki değişikliğin 0,51'ini açıklamaktadır. İkinci modelde ise sembolik tüketimin bağımsız değişken olduğu ve satın alma niyetinin bağımlı değişken olduğu bir regresyon analiz yapılmıştır (Model2). Oluşturulan modelde sembolik tüketim değişkeni satın alma niyeti değişkenindeki değişikliğin $0,44^{\prime}$ ünü açılamaktadır. Oluşturulan üçüncü model sembolik tüketimin bağımsız değişken olduğu, ünlü hayranlığının ve satın alma niyetinin bağımlı değişken olduğu bir regresyon analizi yapılmıştır. Bu modelde sembolik tüketim değişkeninin satın alma niyetinin 0,33'ünü açıkladığı, sembolik tüketim değişkeninin ünlü hayranlığının 0,50'sini açıkladığı görülmektedir. Bu sonuca göre sembolik tüketimin satın alma niyeti üzerindeki etkisinin azaldığı ancak anlamlılı̆̆ını sürdürdüğünü; sembolik tüketim ile satın alma niyeti arasındaki ilişkide ünlü hayranlığının kısmi aracılık etkisi olduğunu söylemek mümkündür.

\section{SONUÇ ve ÖNERILER}

Bu çalışmada geleceğin yetişkin tüketicileri olarak günümüz ön ergen tüketicilerinin sembolik tüketimin satın alma niyeti üzerindeki etkisi ve ünlü hayranlığının aracılık rolü belirlenmeye çalışılmıştır. Postmodern dünyanın günümüz tüketimini en iyi yansıtan kalıplarından biri olan sembolik tüketim şeklinin, pazarlamacılar tarafından önem taşıyan ön ergen tüketicilerdeki yansıması ve bu konuda ünlü hayranlığının rolünün belirleneceği bu çalışmada öncelikle sembolik tüketimin, ünlü hayranlığı ve satın alma niyeti üzerindeki etkilerinin ortaya konması amaçlanmıştır. Bu ilişkilerin yanı sıra ünlü hayranlığı ile satın alma niyeti arasındaki ilişkiler de incelenmiştir.

Araştırmanın amaçlarına uygun olarak oluşturulan hipotezleri test etmek amaciyla yapılan analizler sonucunda sembolik tüketimin ünlü hayranlığı üzerinde anlamlı ve pozitif bir etkisi olduğu görülmüştür. Sembolik tüketim ile satın alma niyeti arasında da anlamlı ve pozitif bir ilişki olduğu görülmüştür. Mevcut yazındaki ilgili çalışmalar ile bu araştırmanın sonuçları karşılaştıııldığında elde edilen bulguların mevcut yazındaki benzer çalışmalar ile büyük oranda örtüştügünü söylemek mümkündür. Bu çalışmayı diğer çalışmadan farklı kılan noktalar hedef kitle olarak ön ergen tüketicilerin seçilmiş olması ve sembolik tüketim ile satın alma niyeti ilişkisinde ünlü hayranlığının aracılık rolünün daha önce incelenmemiş olmasıdır.

Sembolik tüketimin satın alma niyeti üzerine etkisinde ünlü hayranlığının aracılık rolünün incelendiği bu araştırmanın ortaya koyduğu uygulamaya ilişkin sonuçlara göre, sembolik tüketimin ön ergenlerin satın alma niyeti üzerindeki etkili olduğu görülmektedir. Bu sonuç ürün veya markanın başarılı olması için işlevsel özelliklerinin yanı sıra sembolik özelliklerinin de bir etki taşıyabileceğini işaret etmektedir. Bu bağlamda işletmelerin marka ve ürünlerinin 
performansını arttırmak için ürün veya hizmetin sembolik özellikleri açısından farkındalık yaratacak pazarlama faaliyetleri planlamaları yararlı olacaktır. Uygulamacıların ürün ve markalarında sembolik özellikleri ön plana çıkartacak farklılaştırma stratejileri geliştirmeleri rekabet avantajı açısından önemli olacaktır. Ayrıca ön ergenlerin satın alma niyeti üzerinde ünlü hayranlığının etkisinin olduğu da araştırma sonunda elde edilen sonuçlar arasındadır. Bu nedenle hedef kitlesini ön ergenler olarak belirleyen firmaların ve pazarlamacıların bu etkiden yararlanmak için stratejiler geliştirmeleri, ilgili ürün ve markaların tutundurma faaliyetlerinde hayranı olunan ünlülerin kullanılmasının yerinde olacaktır.

\section{KAYNAKÇA}

Ajzen, I. (2005). Attitudes, Personality and Behavior. (2nd Ed.) New York: McGraw-Hill Education, $100,101,115,117-119$.

Albar Özbucak, B. ve Öksüz G. (2013). Marka Farkındalığı Oluşturma Sürecinde Reklamlarda Ünlü Kişilerin Kullanılmasının Tüketicilerin Satın Alma Karar Süreçleri Üzerindeki Etkisi: Giresun İli Araştırması. International Journal of Social Science, 6(8), 417-431.

Aydemir, M. A. (2005). Modern Tüketim Kültürü ve Aile'nin Toplumsal Dönüşümü. Konya Bilgi Yolu; Mesleki Sosyal Kültürel Sanat ve Edebiyat Dergisi, 5, 84-88.

Aydın, A. (2001). Gelişim ve Öğrenme Psikolojisi. Alfa Yayınları, Üçüncü Baskı, İstanbul.

Azizağaoğlu, A. (2010). Sembolik Tüketim: Ürünlerin Sembolik Özelliklerinin Satın Alma Davranışı Üzerine Etkileri. Sakarya Üniversitesi Sosyal Bilimler Enstitüsü, İşletme Anabilim Dalı, Doktora Tezi, Sakarya.

Baron, R. M. and Kenny, D. A. (1986). Distinction in Social Psychological Research: Conceptual, Strategic, and Statistical Considerations. Journal of Personality and Social Psychology, 51(6), 11731182.

Bergeron, J. (2004). Antecedents and Consequences of Salesperson Listening Effectiveness in Buyer-Seller Relationships. The John Molson School of Business, Canada, Doktora Tezi.

Büyüköztürk, Ş. (2005). Sosyal Bilimler İçin Veri Analizi El Kitabı: İstatistik, Araştırma Deseni SPSS Uygulamaları ve Yorum. Pege Yayıncilık, Ankara.

Chan, K.ve Zhang C. (2007). Living in a Celebrity-Mediated Social World: The Chinese Experience. Young Consumers, 8(2), 139-152.

Chiou J. S.; Huang, C. Y. and Chuang, M. C. (2005). Antecedents of Taiwanese Adolescents' Purchase Intention Toward the Merchandise of a Celebrity: The Moderating Effect of Celebrity Adoration. The Journal of Social Psychology, 145(3), 317-334.

Çelik, V. (2003). Eğitimsel Liderlik. Nobel Yayınevi, Ankara.

Çetinkaya, F. Ö. (2019). Sosyal Medyada Gelişmeleri Kaçırma Korkusunun Kişinin Tatil Satın Alma Niyetine Etkisi. Gazi Üniversitesi Sosyal Bilimler Enstitüsü, Turizm İşletmeciliği Anabilim Dall, Doktora Tezi, Ankara.

Dal N. E. ve Dal, V. (2015). Çocukların Tüketici Olarak Sosyalleşme Sürecinde TV Reklamlarının ve Ailenin Rolü Hakkında Teorik Bir Çalışma. Mehmet Akif Ersoy Üniversitesi Sosyal Bilimler Enstitüsü Dergisi, 7(13), 371-388.

Dinç, B. (2010). Ergenlik Döneminde Beden İmgesinin Gelişimi Üzerine Aile, Akran ve Televizyonun Etkilerinin İncelenmesi. Gazi Üniversitesi Eğitim Bilimleri Enstitüsü, Doktora Tezi, Ankara. 
Dodds, W. B.; Monroe, K. B., and Grewal, D. (1991). Effects of Price, Brand, and Store Information on Buyers' Product Evaluations. Journal of Marketing Research, 28(3), 307-319.

Dotson, M. J. and Hyatt E. M. (2005). Major Influence Factors in Children's Consumer Socialization. Journal of Consumer Marketing, 22(1), 35-42.

Dwivedi, A. and Johnson, L.W. (2013). Trust-Commitment as a Mediator of the Celebrity Endorser- Brand Equity Relationship in a Service Context. Australasian Marketing Journal, 21(1), $36-42$.

Engin, H. B. (2013). Çocuk ve Reklam: Çocuklar Olması Gerekenden Erken Büyüyor. I. Türkiye Çocuk ve Medya Kongresi Bildiriler Kitabı -I, 104(5), Çocuk Vakfı Yayınları, İstanbul.

Erzen Ünal, M. ve Yalın Eroğlu, B. (2012). Siyasal Kültürün Temel Paradigmaları Üzerine: Kültürden, Siyasal Toplumsallaşma, Örgütlenme ve Katılma Süreçlerine Yansıyanlar. İstanbul Üniversitesi İletişim Fakültesi Hakemli Dergisi, 41, 49-61.

Fan, Y. and Li, Y. (2009). Children's Buying Behaviour in China. Marketing Intelligence and Planning, 27, 1-31.

Fandos, C. and Flavia'n, C. (2006). Intrinsic and Extrinsic Quality Attributes, Loyalty and Buying Intention: An Analysis for A PDO Pproduct. British Food Journal, 108(8), 646-662.

Featherstone, M. (2005). Postmodernizm ve Tüketim Kültürü. Çev. Mehmet Küçük, 2. Basım, Ayrıntı Yayınları, İstanbul

Gander, M. J. and Gardiner, H. W. (2010). Çocuk ve Ergen Gelişimi. Çev. Bekir Onur, İmge Kitabevi, Ankara.

Gegez, E. (2007). Pazarlama Araştırmaları. Beta Yayıncılık, Geliştirilmiş İkinci Basım, İstanbul.

Grubb, E. L. and Grathwohl, H. L. (1967). Consumer Self-Concept, Symbolism and Market Behavior: A Theoretical Approach. Journal of Marketing, 31(4), 22-27.

Güler, İ. (2013). Kentli Ön Ergen (12-14 Yaş) Öğrencilerin Ebeveynleri ile Zıtlaşma/Çatışma Nedenleri Üzerine Bir Araştırma. Hacettepe Üniversitesi Sosyal Bilimler Enstitüsü Sosyoloji Anabilim Dalı, Yüksek Lisans Tezi, Ankara.

Gültekin, B. ve Erol, Ö. (2014). Ergenlerin Ürün Yerleştirmeye Yönelik Tutum ve Yerleştirilen Ürünlere Yönelik Davranışlarının Sosyalleşme Araçları ile Açıklanması. Hacettepe Üniversitesi İktisadi ve İdari Bilimler Fakültesi Dergisi, 32(1), 113-141.

Haire, M. (1950). Projective Techniques in Marketing Research. Journal of Marketing 14(5), 649-656.

https://www.meb.gov.tr/baglantilar/okullar/index.php?ILKODU=17\&ILCEKODU=1， Erişim Tarihi: 20.04.2018.

İslamoğlu, A.H. (2009). Sosyal Bilimlerde Araştırma Yöntemleri. Beta Basım A.Ş., İstanbul.

Kadığlu Tor, C. (2016). Aile Satın Alma Kararında Ergenlerin Etkisi: Mersin Kentinde Yapılan Bir Araştırma. Mersin Üniversitesi Sosyal Bilimler Enstitüsü, İşletme Anabilim Dalı, Yüksek Lisans Tezi, Mersin.

Kalaycı, Ş. (2006). SPSS Uygulamalı Çok Değişkenli İstatistik Teknikleri. Asil Yayın Dağıtım, Ankara.

Koç, M. (2004). Gelişim Psikolojisi Açısından Ergenlik Dönemi ve Genel Özellikleri. Sosyal Bilimler Enstitüsü Dergisi, 17 (2), 231-256. 
Kozak, Akoğlan M. ve Doğan, M. (2014). Dinleme Davranışının Müşterinin Satın Alma Niyeti ve Satın Alma Davranışına Etkisi: Seyahat Acentası Satış Temsilcileri Kapsamında Bir Araştırma. Eskişehir Osmangazi Üniversitesi Sosyal Bilimler Dergisi, 15(2), 57-83.

Levy, S. J. (1959). Symbols for Sale. Harward Business Review, 37, Temmuz-Ağustos, 117-124.

Lien, C. H.; We, M. J.; Huang, L. C. and Wu, K. L. (2015). Online Hotel Booking: The Effects of Brand Image, Price, Trust and Value on Purchase Intentions. Asia Pacific Management Review, 20 (2015), 210-218.

Lindstrom, M. (2006). Duyular ve Marka-5 Duyuyla Güçlü Markalar Yaratmak. Çev., Ümit Şensoy, 1.B., Optimist Yayınları, İstanbul.

Loudon, D. and Della Bitta, A. J. (1988). Consumer Behavior, Concepts and Applications. New York: Mc Graw-Hill International Editions.

Madran, C. ve Bozyiğit, S. (2013). Çocukların Tüketici Olarak Sosyalleşme Süreci. Çă̆ Üniversitesi Sosyal Bilimler Dergisi, 1(10), Haziran, 71-95.

Martin, C. A. and Bush A. J. (2000). Do Role Models Influence Teenagers' Purchase Intentions and Behavior?. Journal of Consumer Marketing, 17(5), 441-454.

Mascarenhas, O. A.J. and Higby, M.A. (1993). Peer, Parent and Media Influences in Teen Apparel Shopping. Journal of the Academy of Marketing Science, 21(1), 53-58.

Nakip, M. (2006). Pazarlama Araştırmaları Teknikler (SPSS Destekli) Uygulamalar. Seçkin Yayıncılık, İstanbul.

Odabaşı, Y. (2006). Postmodern Pazarlama: Tüketim ve Tüketici. 2.Basım, MediaCat Yayınları, İstanbul.

Özdamar, K. (2010). Paket Programlar ile İstatistiksel Veri Analizi (Çok Değişkenli Analizler). Kaan Kitabevi, 7. Basım, Ankara.

Quliyev, O. (2012). Gösteriş Tüketimi ve Tüketim Tarzlarının İncelenmesi: Azerbaycan Örneği. Sakarya Üniversitesi Sosyal Bilimler Enstitüsü, İşletme Anabilim Dalı, Doktora Tezi, Sakarya.

Sarıkaya, N. ve Barutçu Türkmen, M. (2014). İlk Dönem Çocuk Ergenlerin (11-14 Yaş) Alışveriş Davranışlarında Rol Model Olarak Ünlü Kişi Etkisi. 19. Ulusal Pazarlama Kongresi Bildiriler Kitabı, 405-421, 18-22 Haziran, Gaziantep.

Saunders, M.; Lewis, P. and Thornhill, A. (2009). Research Methods for Business Students. 5. Ed., Prentice Hall.

Schermelleh-Engel, K.; Moosbrugger, H. and Müller, H. (2003). Evaluating the Fit of Structural Equation Models: Tests of Significance and Descriptive Goodness-of-Fit Measures. Methods of Psychological Research Online, 8(2), 23-74.

Schiffman, L. G. and Kanuk, L. L. (2007). Consumer Behavior. 8. Ed., Prentice-Hall Inc, NJ.

Senemoğlu, N. (2010). Gelişim, Öğrenme ve Öğretim Kuramdan Uygulamaya. Gazi Kitabevi, Ağustos, Ankara.

Solomon, M. R. (2003). Tüketici Krallı̆̆ının Fethi. Çev. Selin Çetinkaya, 1. Basım, MediaCat Yayınları, İstanbul.

Sutherland, M. and Sylvester, Al. K. (2003). Reklam ve Tüketici Zihni. Çev. İnci Berna Kalınyazgan, MediaCat Yayınları, İstanbul. 
Şener, A. ve Babaoğul, M. (2007). Çocuk ve Genç Tüketiciler. M. Babaoğul ve A. Şener (Ed.), Tüketici Yazıları I, Ankara: TÜPADEM Yayınları, 127-152.

TDK (2019), Bilim ve Sanat Terimleri Sözlüğü, https://sozluk.gov.tr/, Erişim Tarihi: 02.10.2019.

Tek, Ö. B. (1999). Pazarlama İlkeleri Global Yönetimsel Yaklaşım Türkiye Uygulamaları. 8. Basım, Beta Basım Yayın Dağıtım, İstanbul.

Torlak, Ö.; Altunışı, R. ve Özdemir, Ş. (2006). Postmodern Dünyada Tüketimi Yeniden Anlamlandıracak Yeni Müşteri. Hayat Yayıncılık, İstanbul.

TUIK, "Haber Bülteni", http://www.tuik.gov.tr/PreHaberBultenleri.do?id=33733, Erişim Tarihi:22.05.2020.

TUIK, Türkiye İstatistik Kurumu, Gelir ve Yaşam Koşulları Araştırması Mikro Veri Seti. http://www.tuik.gov.tr/MicroVeri/GYKA_2013/turkce/metaveri/siiniiflamalar/index.html, Erişim Tarihi: 25.04.2019.

Ünal, S. (2014). Göstergebilimsel Açıdan Sembolik Tüketim. 1. Basım, Detay Yayıncılık, Ankara.

Ward, S. (1974). Consumer Socialization: Initial Study Results (Abstract). in NA - Advances in Consumer Research Volume 01, eds. Scott Ward and Peter Wright, Ann Abor, MI: Association for Consumer Research, 120-125.

Wu, P. C. S.; Yeh, G. Y.Y. and Hsiao, C. R. (2011). The Effect of Store Image and Service Quality on Brand Image and Purchase Intention for Private Label Brands. Australasian Marketing Journal, 19(2011), 30-39.

Yeh, H. (2015). Effects of Ict's Innovative Applications on Brand Image and Customer's Purchase Intention. International Journal of Organizational Innovation, 7(4), 31-47.

Yılmaz, V. (2004). Lisrel ile Yapısal Eşitlik Modelleri: Tüketici Şikayetlerine Uygulanması. Sosyal Bilimler Dergisi, 32(8), 783-790.

Yücel, S. (2003). Çocukların Tüketici Olarak Sosyalleşmesi ve Bu Sosyalleşme Sürecinde Ailenin Rolüne Yönelik Bir Araştırma. Anadolu Üniversitesi Sosyal Bilimler Enstitüsü, İşletme Anabilim Dalı, Yüksek Lisans Tezi, Eskişehir.

Zaltman, G. (2003). Tüketici Nasıl Düşünür. Çev. A. Semih Koç, MediaCat Yayınları, İstanbul. 